\section{4. ガ}

\section{1 天然ガス開発・利用の動向}

\section{1. 天然ガス開発の動向}

\section{1. 概 況}

無公害, 低価格, 大量安定供給可能などの有利な面 が注目され，加えて世界的なエネルギーの不足または 危機感，また全世界の石油，天然ガスの埋藏量の $2 / 3$ を有する中東地方の政情不安定, 産油国対メジャ一の 参加権その他をめぐる紛争, ひいては供給の不安定と 言わないまでも，価格の上昇予想等々の情勢下で，天 然ガスの探查開発は例年にも増して広くまた世界的な 規模で活発に推進され, その結果油ガス田の新発見, 開発の進捗の報は世界各地から引きつづいて寄せられ ている。とくにわが国は, そのエネルギー源の中東一 の過度の依存から脱却すべくその供給源の分散を目指 しているが，この点から見て注目す心゙きは，この年に お沙るインドネシア, マレーシア, オーストラリア, タイなどにおける諸発見と開発の進展であろう。ただ し, 豊富な埋蔵を期待され, わが国に最も関係あると 思われる東シナ海, サハリン, 沿海州などの海域にお ける探查開発は, 主として微妙にゆれ動く国際情勢の つり合いに強く支配されるのであろらが，いずれも進 展が見られず, 陸域シベリアに㧍けるヤクートガス田 等の開発の未実現などと相まって, いささかの焦燥を 感じさせる。しかし他面, 天然ガスは燃焼に際し $\mathrm{NO}_{x}$ を発生するといわれ, 無公害原料と一概に言い切れな いこと, また渡洋輸送に不可欠のタンカーの建造費が 最近大幅に值上りしたことが天然ガス開発利用の全計 画資金量の大半—たとえば目下計画中の大西洋横断 計画では投資の $70 \%$ がタンカーの建造費——占める 輸送費を著しく高騰させる結果になることなどは, 天 然ガス利用の将来に影響を与えるであろうことは留意 に值する。

国内においてもこのような情勢をうけて, 探查開発 は前年に引きつついてきわめて活発かつ広範に行なわ れた。その結果として特記すべきは, 新潟県阿賀沖油 ガス田の発見および既存ガス田，ことに吉井-柏崎ガ
ス

ス田における開発の進展, ひいてはその地域からの生 産の増加であって，これが年産 24.7 億 $\mathrm{m}^{3}$ を記録した 原因になっている。この数字はもちろん, わが国産が ス史上最高のものである。

\section{2. 生産 量}

表 4-1 に県別生産量, 対前年増および構成比を示し

\section{表 4-1 県別生産量および対前年增減}

(単位 : $1000 \mathrm{~m}^{3}$ )

1971年 1972 年 対前年增 $\begin{gathered}1972 \text { 年 } \\ (\%)\end{gathered}$

\begin{tabular}{lrrrrr} 
北海 道 & 5377 & 4810 & -567 & 0.19 \\
秋 & 田 & 48233 & 45484 & -2749 & 1.84 \\
山 & 形 & 9649 & 10516 & 867 & 0.42 \\
福 & 島 & 7462 & 4790 & -2672 & 0.19 \\
苂 & 城 & 5416 & 2991 & -2425 & 0.12 \\
新 & 潟 & 1768186 & 1842437 & 74351 & 74.44 \\
長 & 野 & 1049 & 816 & -233 & 0.03 \\
千 & 葉 & 562622 & 542773 & -19849 & 21.93 \\
東 & 京 & 23771 & 18878 & -4833 & 0.76 \\
静 & 岡 & 42 & 39 & -3 & - \\
富 & 山 & 1251 & 1230 & -21 & 0.05 \\
三 & 重 & 309 & 295 & -14 & 0.01 \\
\multicolumn{1}{c}{ 合計 } & 2433457 & 2475059 & 41602 & 100.00
\end{tabular}

た。総生産量は 24 億 7500 万 $\mathrm{m}^{3}$ 余りで，対前年増 4160 万 $\mathrm{m}^{3}$ ，その約 $3 / 4$ が新潟県から，また $1 / 5$ が 4 千葉 県から得られ，この両者を合わせると総生産量の $96 \%$ 以上を占める。第 1 位，第 2 位の順位は前年と同じで あり，第 1 位の新潟県について見れば対前年增は 7400 万 $\mathrm{m}^{3}$ 余で，そのほとんどは吉井一柏崎地域からの増産 による。千葉県については約 2000 万 $\mathrm{m}^{3}$ 減であるが, これは地盤沈下対策として実施されている新規坑井掘 削の停止および既存井からの揚水の規制に基づく結果 である。秋田県は第 3 位とはいらものの, その生産は 调落の一途をたどり対前年 270 万 $\mathrm{m}^{3}$ 減, 構成比はつ いに $2 \%$ \%下となり，かっこの天然ガス王国の面影は 見るべくもない。第 4 位東京の対前年減も坑井の揚水 規制の結果である。 


\section{3. 探査と開発}

47年度に扔いて，国費で実施された天然ガス基䃈調 查および大陸棚石油天然ガス基礎調查の中で，拓洋丸 を用いた基礎物理探查（音波探查および重力調査） は，(1)日高一渡島の，エリモ岬から室蘭南方海域へか けての区域，(2)十勝-釧路のノサップ 岬からエリモ岬 へかけての海域, および(3)沖繩本島, 石垣島, 宮古島 周辺海域で行なわれ，それぞれの海域における地質お よび地質構造の大要を把握した。また基礎物理探査は 北海道天塩町から北方に延びる海岸に沿って行なわれ た。さらにまた基礎調查中の基礎試錐は浜勇知と天草 の 2 坑で行なわれ, 前者は北海道稚内市大字抜海村字 エサシオマナイ地内にあり, 掘削深度は $4520.91 \mathrm{~m}$,
その間, 声問, 稚内, 増幌および鬼志別の各層を掘 削, 後者は熊本県本渡市亀場町大字食場字ツイジ（天 草下島）地内にあり，掘削深度は $2807 \mathrm{~m} ， そ の$ 間に古 第三紀の教良木, 福連木両層および白亜紀の姫の浦, 御所の浦両層群を掘削, それぞれの地点において地質 および地質構造ならびに炭化水素賦存の状況を明らか にしえた。

企業の行なった試掘に対し約 6 億円の探鉱補助金が 交付されたが，表 4-2 に企業会社が試掘，探掘井とし て掘削した坑井中, 成功したものを示した。また，開 発に関し，採掘井として掘削された坑井中の注目され るものを表 4-3 に示した。そのいずれもが吉井-柏崎 ガス田地区のものである。

表 4-2 試探掘井

坑井名 成功月日 掘止深度 仕上 層

\begin{tabular}{|c|c|c|c|c|c|c|c|}
\hline 美 野 & $\mathrm{S} K-3$ & 1.29 & 1997 & 西 & 大 & 舄 & $900 \mathrm{~m}$ \\
\hline 井 & S K-11 & 2.21 & 3184.5 & グ & リ & ン & タ \\
\hline 藤 川 & S K -17 & 2.26 & 3292 & III & & & \\
\hline 長 沢 & S K -1 & 10. 7 & 1800 & グ & リ & 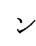 & 夕 \\
\hline 妙法寺 & S K -7 & 11. 29 & 3055 & グ & リ & ン & タ \\
\hline
\end{tabular}

桑 山 -13

12. 16

3590

$3500 \mathrm{~m}$ 層, 桑山-13層

$$
\overbrace{\text { 油 }(\mathrm{k} l)}^{\text {初 }} \underbrace{\text { 産 }}_{\text {ガ ス }\left(\mathrm{m}^{3}\right)}
$$

52000

103000

77000

43000

10000

$$
0.02
$$$$
5
$$

5

取

表 4-3 採

掘止深度 仕 上 層
$(\mathrm{m})$

$26952500 \mathrm{~m}$ 層グリンタフ

2621.5 グ リンタフ

2635 グリンタフ

2950 グ リンタフ

3050 グ リンタフ

2840

1800

1200
グリンタフ

黄 和 田, 大 原

梅 瀬, 大 田 代

\begin{tabular}{|c|c|c|}
\hline 初 & 産 量 & \\
\hline 油 $(\mathrm{k} l)$ & ガス $\left(\mathrm{m}^{3}\right)$ & \\
\hline 22.2 & 84200 & $18 \times \mathrm{F} \mathrm{B}$ \\
\hline 26.2 & 102000 & 7.7 \\
\hline 48.4 & 156000 & $18 \times F B$ \\
\hline 5.56 & 40200 & $18 \times \mathrm{FB}$ \\
\hline 16.8 & 48300 & 3.6 \\
\hline 4.8 & 20680 & $0 \times \mathrm{FB}$ \\
\hline - & 7000 & ポン プ \\
\hline - & 4500 & ポン プ \\
\hline
\end{tabular}

井

\section{4. 阿賀沖油ガス田の発見}

新潟県阿賀野川河口の北方約 $10 \mathrm{~km}$ 付近に, エアガ ン（音波）調查によってその存在を推定されていたド 一ム構造に対して下された試掘井 S 1-1a は46年12月 10 日開坑，47年1月 22 日深度 $3500 \mathrm{~m}$ で掘止め，その 深度 $2092 \mathrm{~m} \sim 2167 \mathrm{~m}$ の間の椎谷層中の 3 層をテスト し, 制限ビーン径 $5 \mathrm{~mm}$ で合計初産ガス量 130 万 $\mathrm{m}^{3} /$ 日, 油量 $230 \mathrm{k} l /$ 日 を得, 次いで, S 1-1 a 北東 $2500 \mathrm{~m}$
に下された S1-2 は 3 月 5 日開坑, 6 月 25 日深度 $4590 \mathrm{~m}$ で掘止め, その深度 $3550 \mathrm{~m}$ 付近の寺泊層中のガス層 をテストし, ビーン径 $19 \mathrm{~mm}$ で初産ガス量 10 万 $\mathrm{m}^{3} /$ 日，また $3270 \mathrm{~m}$ 付近のテストではビーン $6 \mathrm{~mm}$ で, ガス量 14 万 $\mathrm{m}^{3} /$ 日, 油 $5 \mathrm{kl} /$ 日を得た。

引きつづいて S 1-1a の北西 $2500 \mathrm{~m}$ の水深 $82 \mathrm{~m}$ の 地点に下された S 1-3 は 7 月23日開坑, 8 月10日深度 $3518 \mathrm{~m}$ で掘止め, この間に 5 層のガス層を発見, それ 
ぞれのテストの結果, ビーン径 $5 \mathrm{~m} \mathrm{~m}$ で合計初産量ガ ス 140 万 $\mathrm{m}^{3}$ /日, 油 $130 \mathrm{k} l /$ 日, ビーン径 $8 \mathrm{~mm}$ でガス 90 万 $\mathrm{m}^{3} /$ 日，油 $240 \mathrm{k} l /$ 日 を得た。次井 S $1-4$ は S $1-3$ の北東 $2000 \mathrm{~m}$ の水深 $84 \mathrm{~m}$ の地点で下され，9月11 日開坑, 同月 24 日深度 $2400 \mathrm{~m}$ で掘止め, その西山層 上部のガス層をテストし, 初産ガス量 8.2 万 $\mathrm{m}^{3} /$ 日 （ビーン径 $5 \mathrm{~mm}$ ) を得, ここに阿賀沖油ガス田の大 略が確認されるに至り, 現在その開発が検討されてい る。

\section{5. その他}

天然ガスの海外からの輸入はすでにアラスカからの 分が実現しているが，これに続いてブルネイからの計 画が進行中で，その第 1 船が 48 年 1 月 9 日入港した。 その予定輸入量は 7.2 億 $\mathrm{m}^{3} /$ 年 で, これら大量の輸入 ガスは電力, ガス業界に大きく寄与することと思われ る。

また 7 月には石油開発技術センターが石油開発公団 に設置され，その目的は石油，天然ガスの探鉱開発の 技術的中核となり，新技術の導入や開発によりわが国 技術の向上や技術者の養成を行ならこととなってい る。47年度の予算は民間からの寄付1. 15億円を合わせ て6.08億円で，将来が大きく期待される。

\section{2. 天然ガス利用の動向}

天然ガスは, 燃料, 原料としての優位性ならびに最 近, 環境の保全上クリーンエネルギーとしての重要性 が認識されるに及び，国内に㧍ける探鉱，開発の促進 と諸外国からの LNG の輸入が本格化し, 新潟沖大陸 棚油田・ガス田の成功とアラスカからの LNG 輸入に 続いてブルネイからの輸入開始ならびに中東からの数 々の輸入プロジェクトの進展などにより, 今後ますま すその需要は増大するものと期待されるに至った。

世界の天然ガス埋蔵量は，1971年末において約 49.5 兆 $\mathrm{m}^{3}$ と前年に比して約 $19 \%$ 増加し, 生産量は 1.26 兆 $\mathrm{m}^{3}$ に達し世界の一次エネルギー需要中の約 $18 \%$ は天 然ガスにより賄われた。

天然ガス賦存地域は, 北アメリカ, 西ヨーロッパ, 北アフリカ, 中東拉よび東ヨーロッパと従前どおりで あったが，アメリカの埋蔵量は 1970 年末 8.2 兆 $\mathrm{m}^{3}$ が1971年末には $4.1 \%$ 減, 7.86 兆 $\mathrm{m}^{3}$ となったのに対 し, ソ連の埋蔵量は1970年末 12.0 兆 $\mathrm{m}^{3}$ が約 $50 \%$ 増, 18 兆 $\mathrm{m}^{3}$ と急激に増大したほか, 西ヨーロッパ, 北了 フリカおよび中東の各地域においてもそれぞれ増加を
示した。

国内の天然ガス利用の状況は表 4-4 に示すとおり,

\section{表 4-4 天然ガスの産業別販売量}

\author{
産 業 別
}

化学 工 業

その他の製造業

発電

都市ガ ス

運輸

そ の他

合計

$$
\text { 貝 }\left(1000 \mathrm{~m}^{3}\right)
$$

1258861

370161

177039

558709

828

13665

2379263
構 成 比

52.91

15.56

7. 44

23. 48

0.03

0.58

100.00
南関東ガス田における数次にわたる水溶性天然ガス採 取規制のため減産の止むなきにいたった。反面，新潟 県下における遊離型ガス田の開発によりほぼ前年同様 の約 23.79 億 $\mathrm{m}^{3}$ の天然ガスが販売された。産業別販 売割合は化学工業用 $52.91 \%$, 都市ガス用 $23.48 \%$, その他製造業 $15.56 \%$ ，発電用 $7.44 \%$ の割合で化学 工業用が過半量を占めた。

輸入 LNG については, アラスカからの東京瓦斯根 岸工場への輸入は前年に引きつづき順調に操業され， さらにブルネイからの LNG 輸入第 1 船が 47 年 12 月 15 日大阪瓦斯泉北工場に到着したのに続いて 48 年 1 月 9 日には東京瓦斯根岸工場にも LNG を積載して入港 し，都市ガス原料，発電用燃料としての利用が確立さ れるに至った。

\section{1. 化学工業用}

天然ガスを原料として使用する化学工業会社は 6 社 7 事業所と前年より減少し，使用された天然ガス量は 約 12.58 億 $\mathrm{m}^{3}$ で大部分がメタノール, アンモニア に，一部がその他有機薬品の製造原料として消費され た。

メタノール生産量は, 天然ガスを原料とした 3 工場 が閉鎖または原料を他に転換したため，天然ガスを原 料とするもの 39 万 $4167 \mathrm{t}$ と全生産量 95 万7 $7996 \mathrm{t}$ 中の 41. 4\% と前年に比し 26 万 $5017 \mathrm{t}$ の減産となった。

アンモニアの生産量は，天然ガスを原料とするもの 34 万 $6228 \mathrm{t}$ と前年より約 1 万 $4000 \mathrm{t}$ 増産して全生産量 375 万 $2534 \mathrm{t}$ 中の $9.2 \%$ 生産し, 二次成品としてホル マリン，硫安および尿素が製造された。

\section{2. 都市ガス用}

全国の都市ガス事業者数 243, 内，天然ガスを主原 料とする事業者数 61 , 需要家件数約 1178 万件と前年に 比較して $7.6 \%$ の増加を示し, 都市ガス事業は首都圏 
を始め全国において順調な発展を示した。

都市ガス用として販売された天然ガス量は約5.59億 $\mathrm{m}^{3}$ で, 全国都市ガス販売量約 53 億 $\mathrm{m}^{3}$ (10.010 kcal/ $\mathrm{m}^{3}$ ) 中の約 $10.5 \%$ を占めた。なお, 輸入 $\mathrm{LNG}$ 使用 量は約 23.7 万 $\mathrm{t}$ であった。

\section{3. 発 電用}

発電用として供給された天然ガス量は約 1.77 億 $\mathrm{m}^{3}$ で, 北海道豊富ガス田では 361 万 $\mathrm{m}^{3}$ のガスがガスタ 一ビン発電用燃料として，また新潟県下では約 1.73 億 $\mathrm{m}^{3}$ の天然ガスが発電用燃料として利用された。

なお，アラスカからの輸入 LNG の大部分は東京電 力南横浜火力発電所 No. 1 号基, No. 2 号基のボイラ 一燃料として使用された。

\section{4. その他の製造業}

金属の精鍊，製鋼，葖業および一般加熱用燃料とし て需要はあるものの生産量不足のため販売量注約 3.70 億 $\mathrm{m}^{3}$ に止まり, その販売構成比率は約 $15.6 \%$ であ った。

最後に，天然ガスの品質上の優秀性をふまえて天然 ガスの安定供給について適切な施策の確立が期待され る。

\section{2 都市ガス工業の動向}

\section{1. 概 況}

昭和 47 年度に㧍ける都市ガスの販売量は 5256.5 万 $\times$ $10^{6} \mathrm{kcal}$ で, 前年に比し 410.2 万 $\times 10^{6} \mathrm{kcal}$ で $8 \%$ 増, 需要家戸数は 1171 万戸に達し 70 万戸増で $7 \%$ の伸び を示した。

本年度は第 4 次 5 力年計画の最終年度であるが, 計 画に対しガス販売量, 需要家戸数とも, 順調な達成率 となる見込みである。表 4-5 に都市ガス需給計画（第 4 次 5 力年計画), 表 4-6 亿都市ガス製造用原料消費 計画および副産物計画を示す。

ガス事業者関係諸法令の施行については,

（1）悪臭物質に指定されて規制基準が設けられたも の 5 物質 (硫化水素, メチルメルカプタン, 硫化メチ ル，アンモニア，トリメチルアミン）について，47年 5 月より悪臭防止法の施行基準が適用された。

(2) ガス事業法の一部改正による 5 品目（ガススト 一プ，ガスバーナ一付風呂がま, ガス風呂バーナー, ガス風呂バーナー元栓, ガス瞬間湯沸器) の器具につ

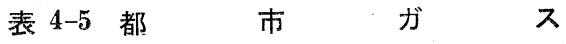

45年度

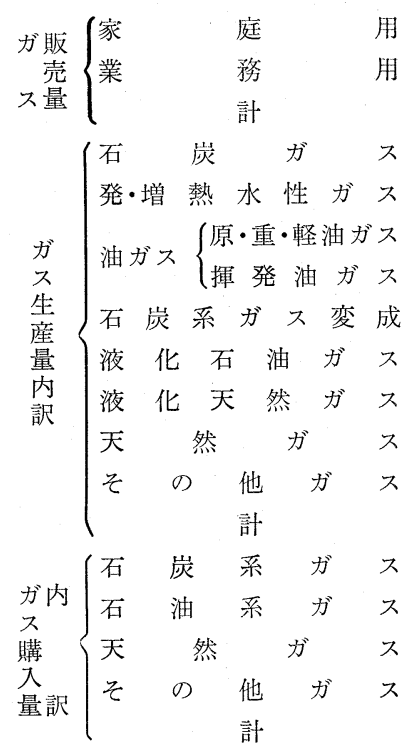

ガス生産・購入量計
2943. 2

1628. 2

4571.4

$1261.0(24.3)$

$20.7(0.4)$

$748.5(14.4)$

$1088.5(21.0)$

$32.1(0.6)$

212.9 ( 4.1$)$

$314.4(6.1)$

$45.9(0.9)$

$4.9(0.1)$

$3728.9(71.9)$

647.8 ( 12.5$)$

384.9 ( 7.4)

423.8 ( 8.1$)$

$3.4(0.1)$

$1459.9(28.1)$

$5188.8(100.0)$
46年度

3259.5

1703. 1

4962.6

1152.8 ( 20.7)

$41.3(0.7)$

$696.2(12.5)$

1305.8 ( 23.5)

$39.8(0.7)$

$326.0(5.9)$

$333.4(6.0)$

$43.0(0.8)$

$4.3(0.1)$

$3942.6(70.9)$

673.2 ( 12.1)

481.6 ( 8.7)

$456.9(8.2)$

$2.9(0.1)$

1614. 6 ( 29. 1)

$5557.2(100.0)$
47年度

3652.8

1865.1

5517.9

1085.6 ( 17.6$)$

$55.5(0.9)$

695.5 ( 11.3 )

1678.3 ( 27.3)

$47.9(0.7)$

$427.4(7.0)$

$484.5(7.9)$

$42.6(0.7)$

$5.1(0.1)$

$4522.4(73.5)$

$609.7(9.9)$

$515.0(8.4)$

$497.0(8.1)$

$4.7(0.1)$

$1626.4(26.5)$

$6148.8(100.0)$

（注）ガス量は $10000 \mathrm{kcal} / \mathrm{m}^{3}$ 。（）内は構成比\% 出所: ガス事業便覧, 昭和 47 年版 
いて，47年 7 月より検定制度が実施された。

(3) 労働安全衛生法の新法が47年10月 1 日より施行 され,これにより具体的な安全基準が確立された。

(4) 地域冷暖房など一般の需要家に応じて, 熱の供 給を行なら事業に対して48年 2 月より事業法が施行さ れることになった。

1. ガス事業者数

本年度都市ガス供給を開始した事業者は 245 で, 私 営 172, 公営73となった。表 4-7 に新規ガス事業開始 者，表 4-8 に計画中のガス事業者を示す。

\section{2. 熱量変更事業者}

供給ガスの熱量変更（カロリーアップ）を行なった のは，表 4-9 にその事業者を示す。これによると5000 $\mathrm{kcal}$ は $6,7000 \mathrm{kcal}$ は 1,1 万 kcal は 5 で, 計 12 事 業者である。

\section{2. ガスの供給}

1. 需要家戸数

昭和47年12月末における需要家戸数（取付メーター 数）は 1170 万 9167 戸で，その内訳は家庭用 1102 万 5330 (94.1\%), 商業用 52 万 8131 (4.5\%), 工業用 5 万 4261 $(0.5 \%)$, その他 10 万 $1445(0.9 \%)$ で, 前年度に比
較すると $7 \%$ の増加となり, 昭和 45 年 $108 \%$, 昭和 46 年 $107 \%$ と同程度の伸びを示している。なお, 構成率 は前年と同じ割合となっている。

\section{2. ガスの販売量}

ガスの販売量は昭和 45 年 $114.7 \%$, 昭和 46 年 109.0 $\%$, 昭和 47 年 $108.5 \%$ と順調な伸びを示し, 昭和 47 年 の内訳は, 家庭用 $109.4 \%$, 商業用 $106.9 \%$, 工業用 $107.4 \%$ ，その他 $104.2 \%$ で前年とほぼ同様な傾向で ある。

ガス販売量の構成率は家庭用において, 昭和45年 $64.1 \%$ ，昭和 46 年 $65.4 \%$, 昭和 47 年 $65.9 \%$ となり, 前 年と同じ傾向で商業用, 工業用は昭和 46 年に比し若干 低下の傾向にある。図 4-1 に年別ガス需要家数構成比 を, 図 4-2 に年別販壳量構成比を示す。

\section{3. ガスの製造}

1. 製造設備

本年中における新設ガス発生設備を表4-10に示す。

2. ガス製造

昭和 47 年のガス生産量（購入ガス量を含む）は 4200 億 kcal で前年に比し 8.5\% の増加となり, 石炭系ガ スは前年より少なく $94 \%$ に低下しているが, 石油系ガ

\begin{tabular}{rl}
\multicolumn{1}{l}{ 需 } & \multicolumn{1}{l}{ 詥 } \\
& \multicolumn{1}{l}{ 画 } \\
48 年度 & \multicolumn{1}{l}{ 年度 } \\
4110.3 & 4585.9 \\
2162.2 & 2358.4 \\
6272.5 & 6944.3 \\
$1130.5(16.2)$ & $1151.9(15.0)$ \\
$20.3(0.3)$ & $16.0(0.2)$ \\
$574.8(8.2)$ & $571.9(7.4)$ \\
$1766.8(25.3)$ & $2002.0(25.0)$ \\
$53.1(0.8)$ & $61.9(0.8)$ \\
$373.9(5.4)$ & $426.6(5.5)$ \\
$1197.4(17.2)$ & $1576.0(20.5)$ \\
$22.2(0.3)$ & $13.6(0.2)$ \\
$5.2(0.1)$ & $5.5(0.1)$ \\
$5144.2(73.8)$ & $5825.4(75.7)$ \\
$634.6(9.1)$ & $654.4(8.5)$ \\
$577.1(8.3)$ & $600.8(7.8)$ \\
$607.3(8.7)$ & $613.8(7.9)$ \\
$5.0(0.1)$ & $5.4(0.1)$ \\
$1824.0(26.2)$ & $1874.4(24.3)$ \\
$6968.2(100.0)$ & $7699.8(100.0)$
\end{tabular}

(単位 100 万 $\mathrm{m}^{3}$ )

\begin{tabular}{|c|c|c|c|}
\hline $46 / 45$ & $47 / 46$ & $48 / 47$ & $49 / 48$ \\
\hline 110.7 & 112.1 & 112.5 & 111.6 \\
\hline 104.6 & 109.5 & 115.9 & 109.1 \\
\hline 108.6 & 111.2 & 113.7 & 110.7 \\
\hline 91.4 & 94.2 & 104. 1 & 101.9 \\
\hline 200.2 & 134.3 & 36.5 & 79.0 \\
\hline 93.0 & 99.9 & 82.6 & 99.5 \\
\hline 120.0 & 128.5 & 105.3 & 113.3 \\
\hline 124.0 & 120.2 & 111.0 & 116.5 \\
\hline 153. 1 & 131. 1 & 87.5 & 114. 1 \\
\hline 106.1 & 145.3 & 247. 1 & 131. 6 \\
\hline 93.6 & 99.1 & 52.2 & 61.1 \\
\hline 87.0 & 117.7 & 101.6 & 105.5 \\
\hline 105.7 & 114.7 & 113.7 & 113.2 \\
\hline 103.9 & 90.6 & 104.1 & 103. 1 \\
\hline 148.2 & 106.9 & 112.1 & 104.1 \\
\hline 107.8 & 108.8 & 122.2 & 101.1 \\
\hline 84.3 & 163.1 & 106.5 & 106.8 \\
\hline 110.6 & 100.7 & 112.2 & 102.8 \\
\hline 107.1 & 110.6 & 113.3 & 110.5 \\
\hline
\end{tabular}


表 4-6 年度別（45 48年）都市ガス製造原料消費およびコークス需給表（計画，実績）

\begin{tabular}{|c|c|c|c|c|c|c|c|c|c|c|c|c|}
\hline & & & & & & & & & & & & \\
\hline & & & & & & 上 期 & 期 & & 期 & & & \\
\hline & （石 & 石炭ガ ス 用 & 用 $(1000 t$ & & 7139.4 & 3270.0 & 3244.3 & 14.3 & 31.4 & 2157.8 & 189.2 & 448.7 \\
\hline & 炭 & $\{$ 加熱用・その他用 & 月 $(11$ & ) & 0.4 & 2.3 & 0 & 2.3 & - & - & - & - \\
\hline & घR & 発生炉ガス用 & 用 $(\prime \prime$ & ) & 36.9 & 15.3 & 47.2 & 62.5 & 14.8 & 30.7 & 45.5 & 1.9 \\
\hline & $\begin{array}{l}1 \\
3\end{array}$ & \{增熱水 性 ガス用 & 月 $(11$ & ) & 1.3 & 0 & 5.4 & 5.4 & 7.6 & 13.4 & 21.0 & 2.7 \\
\hline & & 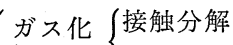 & 㔖 $(1000 \mathrm{k}$ & & 283.9 & 99.4 & 12.4 & 1.8 & 72.0 & 134.4 & 6.4 & 38.8 \\
\hline & 原 & 熱 分 解 & 粱 ( I & ) & 846.4 & 311.8 & 525.5 & 7.3 & 320.1 & 544.9 & 65.0 & 54. \\
\hline & 重 & 加 & 月 $(\prime \prime$ & ) & 58.3 & 6. & .5 & & & 8.4 & 7.3 & 8.2 \\
\hline & 軽 & 増 & 月 $(\prime \prime$ & 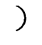 & 0.1 & - & - & - & - & - & - & - \\
\hline & 油 & その他 用 & 月 $(11$ & 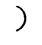 & 0.7 & 0.2 & 0 & 0.2 & - & - & - & - \\
\hline & & & ( ) & ) & 1289.4 & 468.2 & 728.4 & 6 & 41.0 & 767.7 & 1208.7 & 01.6 \\
\hline & & 吕ス化 接触分解 & 啐 ( I & ) & 1357.3 & 464.1 & 146.0 & 0.1 & 07.6 & 1372.1 & 9.7 & 15.0 \\
\hline & 灯 & 熱 分 解 & 㧝 ( I & ) & 44.0 & 17.9 & 23.2 & 41.1 & 19. & 25.6 & 5.3 & 9.4 \\
\hline & 揮 & 熱 & 月 $(11$ & ) & 199.6 & 55.0 & 191.4 & 6.4 & 97 & 222.4 & 0.3 & 94.2 \\
\hline & 発 & 増 & 月 $(11$ & ) & 2.4 & 0.1 & 11.9 & 12.0 & 13.0 & 23.1 & 36.1 & 4. 6 \\
\hline & 反泪 & その他 用 & 月 $(11$ & ) & - & - & - & - & - & - & - & - \\
\hline & & & $\prime \prime$ & ) & 1603.3 & 537.1 & 1372.5 & 09.6 & 38.2 & 1643.2 & 1.4 & 63.2 \\
\hline & 液 & ス 化 用 & 月 $(1000 \mathrm{t}$ & t) & 6.1 & 74.7 & 4.0 & 88.7 & 23.8 & 28.1 & 1.9 & 88.9 \\
\hline & 华 & 熱 & 月 $(11$ & ) & - & - & - & - & - & - & - & - \\
\hline & 石 & 増 & $A(1)$ & & - & - & - & - & - & - & - & - \\
\hline & 出 & の 他 & A $(1)$ & ) & 0.1 & 0.4 & 4.3 & 4.7 & - & - & - & . \\
\hline & Z & 計 & $(1)$ & ) & 76.2 & 75.1 & 8.3 & 73.4 & 23.8 & 28.1 & 1.9 & 8.9 \\
\hline & 液 & 窃 & ( & ) & 8.8 & 65.8 & 22.3 & .1 & 91.1 & 215.4 & .5 & 4.1 \\
\hline & 耊 & 変 & 月 $(11$ & 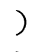 & 57.7 & .1 & 6.6 & 7 & 16. & 23.2 & 9.4 & 7.1 \\
\hline & 天 & 加 & A $(11$ & ) & 24.7 & 15.2 & 3.5 & 8.7 & 6.8 & 9.9 & 6.7 & 36.2 \\
\hline & ガ & そ & (1) & (3) & 0 & 一 & - & - & - & - & - & - \\
\hline & x & 計 & ( 11 & ) & 1.2 & 8.1 & 2.4 & 0.5 & 4.1 & 248.5 & 2.6 & 37.4 \\
\hline & & 購 入 & $(1000 \mathrm{~m}$ & & 478925 & 204853 & 304986 & 509839 & 227006 & 327336 & 554342 & 620487 \\
\hline & 然 & 入\{自家生産分 & $(1)$ & ) & 14847 & 5397 & 6297 & 694 & 5379 & 6157 & 36 & 536 \\
\hline & 吕 & 消 未変成用 & A $(1)$ & ) & 454061 & 196167 & 286794 & 482961 & 213861 & 314178 & 528039 & 619349 \\
\hline & $1 \pi$ & 費 $\{$ 変 成 & A $(1)$ & ) & 711 & 083 & 489 & 572 & 524 & 15 & 339 & 674 \\
\hline & 生 & 産 & $(1000 \mathrm{t}$ & ) & 5162.2 & 42.1 & 15.4 & 57.5 & 7.8 & 2263.5 & 4441.3 & 4625.1 \\
\hline & 購 & 入 & $(11$ & ) & 0.1 & 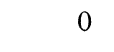 & . & - & - & - & - & - \\
\hline & 自 & 熱 & $(11$ & ) & 1.6 & 0.1 & 0.6 & 0.7 & 0. & 0.3 & 0.5 & 0.5 \\
\hline & 家 & ガ ス 化 用 & A $(\prime \prime)$ & 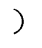 & 38.2 & 15.3 & 52.6 & 67.9 & 22. & 44.1 & 6.5 & 4.6 \\
\hline & 費 & の 他 用 & A $(1)$ & ) & 41.9 & 20.8 & 24.4 & 45.2 & 25.3 & 24.1 & 49.4 & 7.7 \\
\hline & 量 & 計 & ( 11 & ) & 81.7 & 36.2 & 77.6 & 113. 8 & 47.9 & 68.5 & 16.4 & 2.8 \\
\hline
\end{tabular}

出所：ガス課資料

表 4-7 昭和 47 年新規 ガス事業開始者

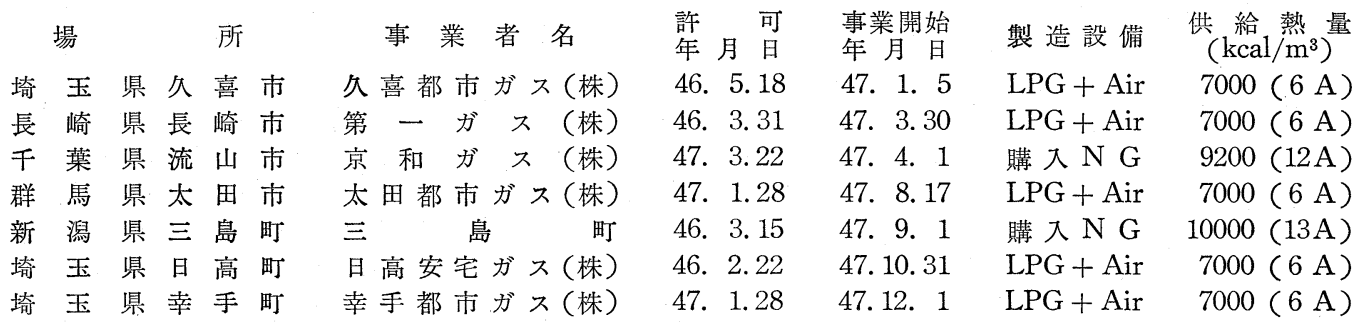


表 4-8 計画中のガス事業者 (予定)

\begin{tabular}{|c|c|c|c|c|c|}
\hline 所 & 事業 者 名 & $\begin{array}{ll}\text { 許 } & \text { 可 } \\
\text { 年 月 } & \text { 日 }\end{array}$ & $\begin{array}{l}\text { 製 造 設 備 } \\
\text { (予 定) }\end{array}$ & $\begin{array}{c}\text { 供 給熱 量 (予定) } \\
\left(\mathrm{kcal} / \mathrm{m}^{3}\right)\end{array}$ & 供給開始 \\
\hline 埼玉 県入間 市 & 入 間 ガ ス (株) & 46. 8.17 & $\mathrm{LPG}+\mathrm{Air}$ & $7000(6 \mathrm{~A})$ & - \\
\hline 埼玉県鶴 ガ島 町 & 鶴 ガ 島 ガ ス (株) & - & $\mathrm{LPG}+$ Air & (予定) 7000 (6 A) & - \\
\hline 新 潟 県 青 海 町 & 青 海 ガ ス (株) & - & 購 入 N G & $(\prime \prime)) 10000(13 \mathrm{~A})$ & - \\
\hline 群 馬 県 渋 川 市 & 渋 川 ガ ス (株) & - & $\mathrm{LPG}+\mathrm{Air}$ & $(\prime \prime) 7000(6 \mathrm{~A})$ & - \\
\hline 静 岡 県 袋 井 市 & 袋 井 ガ ス（株） & - & $\mathrm{LPG}+\mathrm{Air}$ & $(\prime \prime) 7000(6 \mathrm{~A})$ & - \\
\hline 埼玉県東松山市 & 松 栄 ガ ス (株) & - & $\mathrm{LPG}+\mathrm{Air}$ & $(\prime \prime) 7000(6 \mathrm{~A})$ & - \\
\hline 埼 玉県 坂 & 坂 戸 ガ ス（株） & - & $L P G+$ Air & $(\prime \prime) 7000(6 \mathrm{~A})$ & - \\
\hline
\end{tabular}

\section{表 4-9 熱量変更実施事業者}

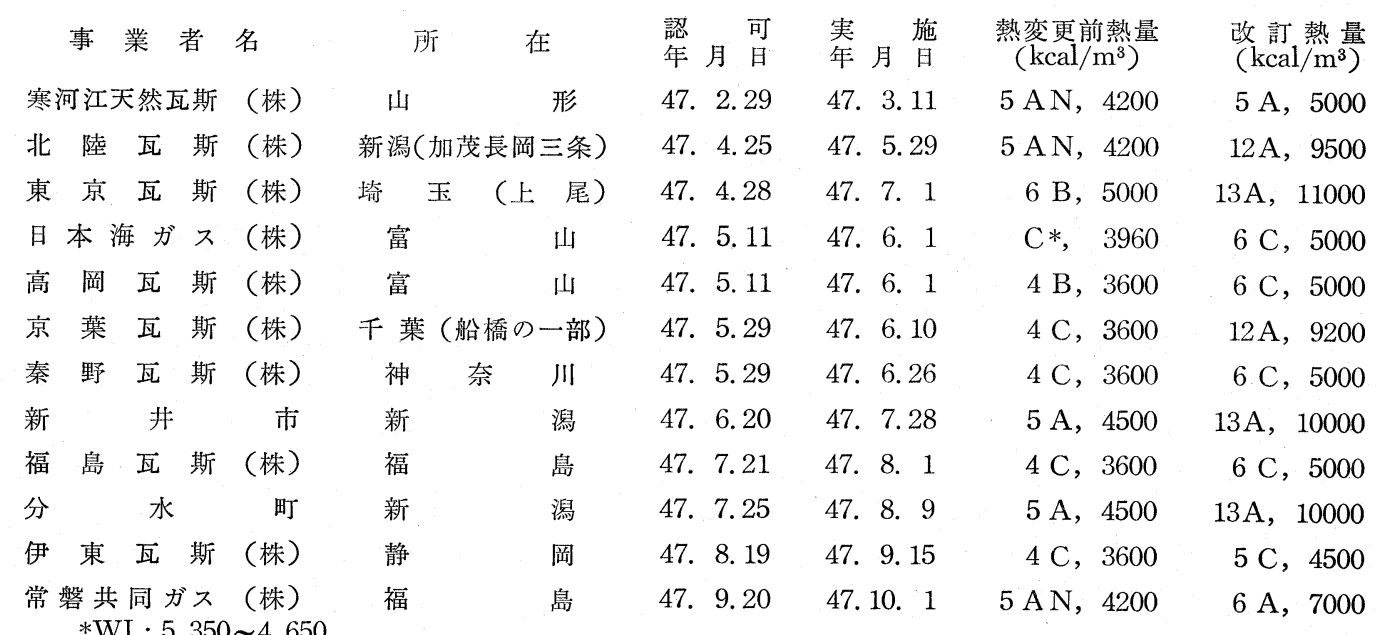

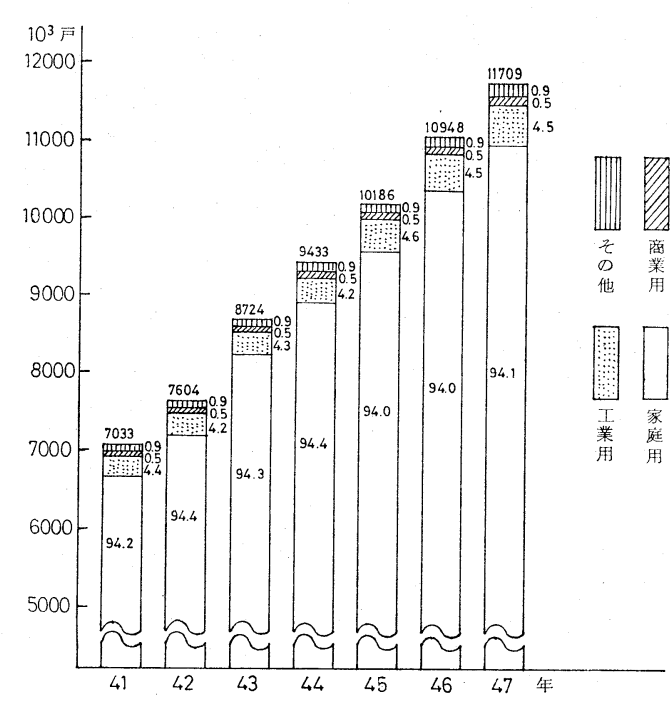

図 4-1 年別ガス需要家数構成比

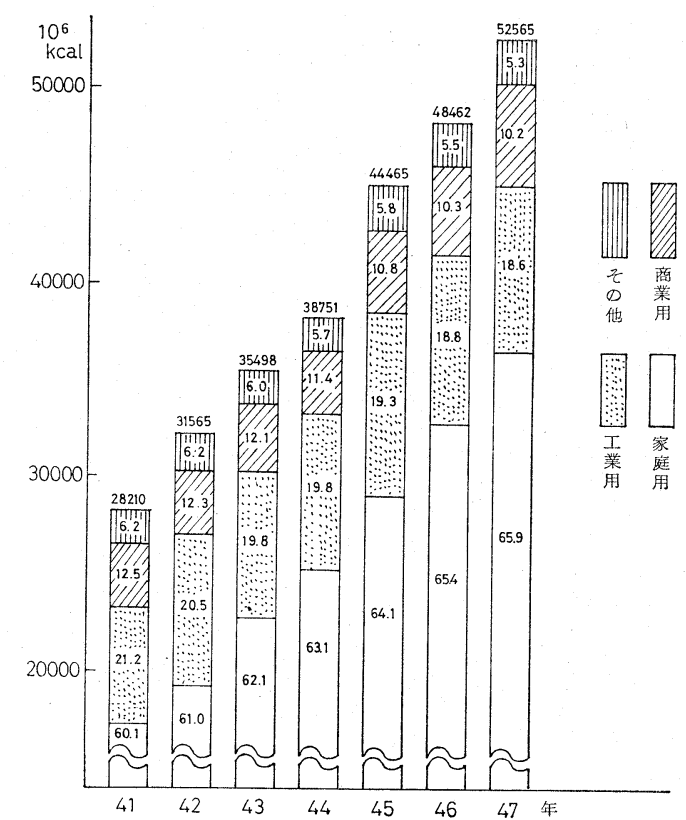

図 4-2 年別ガス販売量構成比 
表 4-10 ガス製造設備新増設調査表 $(47 / 1 \sim 47 / 12)$

\begin{tabular}{|c|c|c|c|c|c|c|c|c|c|}
\hline 事 業者名 & 工 場 名 & 装 置 名 & $\begin{array}{l}\text { 基 } \\
\text { 数 }\end{array}$ & 原 料 & ${ }_{(\mathrm{k} l}^{\text {使 } 7 \text { 日 })^{\text {量 }}}$ & $\stackrel{\text { 能 } \text { 力 }}{\left(\mathrm{m}^{3} / \text { 日 }\right)}$ & $\begin{array}{l}\text { 供給 } \\
\text { 熱量 }\end{array}$ & $\begin{array}{l}\text { 燃燒 } \\
\text { 性 }\end{array}$ & $\begin{array}{l}\text { 建 設 } \\
\text { 年 月 }\end{array}$ \\
\hline 東京瓦斯(株) & 大 森工場 & OR G & 1 & オフガス & $141000.0 \mathrm{~m}^{3} /$ 日 & 220000 & 5.000 & $6 \mathrm{~B}$ & 47.10 \\
\hline$\prime \prime$ & 豊 洲 工 場 & I C I & 1 & ナフサ & 540.0 & 741000 & 5000 & $6 \mathrm{~B}$ & 47.11 \\
\hline 大阪瓦斯(株) & 泉 北工場 & I C I & 2 & ナフサ & 420.0 & 625000 & 4500 & $6 \mathrm{C}$ & 47.12 \\
\hline$\prime \prime$ & $\prime \prime$ & L N G 気化装置 & 2 & $\mathrm{LNG}$ & $960.0 \mathrm{t} /$ 日 & 2807000 & 4500 & $6 \mathrm{C}$ & 47.12 \\
\hline 東邦瓦斯(株) & 空見工場 & $\mathrm{STG}$ & 1 & ナフサ & 303.0 & 500000 & 4500 & $6 \mathrm{C}$ & 47. 10 \\
\hline 旭川瓦斯(株) & & $P-9$ & 1 & ナフサ & 72.3 & 140000 & 3600 & $4 \mathrm{C}$ & 47. 8 \\
\hline 千 歳 市 & 新 設 工 場 & NRG-CR & 2 & ナフサ & 10.7 & 20000 & 3600 & $4 \mathrm{~B}$ & 47.12 \\
\hline 水沢ガス(株) & $\begin{array}{l}\text { 新設都市ガ } \\
\text { ス工場 }\end{array}$ & $\begin{array}{l}\text { 温水式液化石油 } \\
\text { ガス発生装置 } \\
\mathrm{NK} \mathrm{K} \text {-60-S P }\end{array}$ & 1 & ブタン & $9400 \mathrm{~kg} /$ 日 & 16800 & 7000 & $\mathrm{~A}$ & 47. 11 \\
\hline 弘前瓦斯(株) & & $\mathrm{NGC}-7$ & 2 & ナフサ & 23.0 & 30000 & 5000 & $6 \mathrm{C}$ & 47. 8 \\
\hline 仙 台 市 & 港 I 場 & $\mathrm{OG}$ & 2 & ナフサ & 20.0 & 25000 & 5000 & $6 \mathrm{C}$ & 47.12 \\
\hline 福島瓦斯(株) & & $\mathrm{NG} \mathrm{C}-7$ & 2 & ナフサ & 46.2 & 60000 & 5000 & $6 \mathrm{C}$ & 47.10 \\
\hline $\begin{array}{l}\text { 常磐共同ガス } \\
\text { (株) }\end{array}$ & & $\begin{array}{l}\text { 温水式液化石油 } \\
\text { ガス発生装置 }\end{array}$ & 2 & ブタン & $36000 \mathrm{~kg} /$ 日 & 60000 & 7000 & $6 \mathrm{~A}$ & 47. 4 \\
\hline 飯坂ガス(株) & & NKG-1000-VM & 1 & ブタン & $26400 \mathrm{~kg} /$ 日 & 48000 & 7000 & $6 \mathrm{~A}$ & 47. 11 \\
\hline 京葉瓦斯(株) & 市川工場 & MR G & 1 & ナフサ & 221.0 & 500000 & 3600 & $4 \mathrm{C}$ & 47. 12 \\
\hline$\prime \prime$ & $\prime \prime$ & $\begin{array}{l}\text { 液化石油ガス発 } \\
\text { 生装㯰 }\end{array}$ & 1 & ブタン & $9500 \mathrm{~kg} /$ 日 & $\begin{array}{r}3500 \\
(32000 \\
\left.\mathrm{kcal} / \mathrm{m}^{3}\right)\end{array}$ & 3600 & $5 \mathrm{C}$ & 47.12 \\
\hline 谷村瓦斯(株) & & MS & 1 & ナフサ & 7.7 & 10000 & 5000 & $6 \mathrm{~B}$ & 47. 11 \\
\hline 伊東瓦斯(株) & & MS & 1 & ナフサ & 17.4 & 24000 & 4500 & $5 \mathrm{C}$ & 47.12 \\
\hline 佐野瓦斯(株) & & $\begin{array}{l}\text { 温水式液化石油 } \\
\text { ガス発生設備 }\end{array}$ & 1 & ブタン & $14400 \mathrm{~kg} /$ 日 & 24120 & 7000 & $6 \mathrm{~A}$ & 47. 4 \\
\hline 新 井 市 & & $\begin{array}{l}\text { 液化石油ガス発 } \\
\text { 生設備 }\end{array}$ & 1 & L P G & $480 \mathrm{~kg} /$ 日 & $\begin{array}{r}240 \\
(25000 \\
\left.\mathrm{kcal} / \mathrm{m}^{3}\right)\end{array}$ & 10000 & $13 \mathrm{~A}$ & 47. 7 \\
\hline 島田瓦斯(株) & & $\begin{array}{l}\text { 温水式液化石油 } \\
\text { ガス発生設備 }\end{array}$ & 1 & L P G & $4800 \mathrm{~kg} /$ 日 & 8160 & 7000 & $6 \mathrm{~A}$ & 47. 6 \\
\hline 角栄瓦斯(株) & $\begin{array}{l}\text { 西坂戸事業 } \\
\text { 所 }\end{array}$ & $\prime \prime$ & 2 & L P G & $12000 \mathrm{~kg} /$ 日 & 19200 & 7000 & $6 \mathrm{~A}$ & 47. 8 \\
\hline $\begin{array}{l}\text { 新日 本瓦斯 } \\
\text { (株) }\end{array}$ & & $\begin{array}{l}\text { 温水式ベーパー } \\
\text { ライザーミキサ } \\
\text { - }\end{array}$ & 1 & L P G & $9600 \mathrm{~kg} /$ 日 & 16800 & 7000 & $6 \mathrm{~A}$ & 47.12 \\
\hline 東武ガス(株) & & $\begin{array}{l}\text { 温水式ブタン発 } \\
\text { 生装置 } \\
\text { NK G-1000 }\end{array}$ & 1 & ブタン & $26400 \mathrm{~kg} /$ 日 & 48000 & 7000 & $6 \mathrm{~A}$ & 47. 12 \\
\hline 習 志 野 市 & 藤崎供給所 & $\begin{array}{l}\text { 液化ガス気化装 } \\
\text { 置 }\end{array}$ & 1 & L P G & $2400 \mathrm{~kg} /$ 日 & 3120 & 9200 & $12 \mathrm{~A}$ & （未着工） \\
\hline 武陽ガス(株) & 羽村工場 & $\begin{array}{l}\text { 温水式液化石油 } \\
\text { ガス気化装置 }\end{array}$ & 1 & ブタン & $9600 \mathrm{~kg} /$ 日 & 16800 & 7000 & $6 \mathrm{~A}$ & 47. 10 \\
\hline 上 越 市 & 川 原 町 & $\begin{array}{l}\text { ガス加熱温水式 } \\
\text { 液化石油ガス }\end{array}$ & 1 & L P G & $2400 \mathrm{~kg} /$ 日 & $\begin{array}{r}1200 \\
(24000 \\
\left.\mathrm{kcal} / \mathrm{m}^{3}\right)\end{array}$ & 4500 & $5 \mathrm{~A}$ & （未着工） \\
\hline$\prime \prime$ & 北 本 町 & 気 化 装 置 & 1 & L P G & $2400 \mathrm{~kg} /$ 日 & $\prime \prime$ & 4500 & $5 \mathrm{~A}$ & （未着工） \\
\hline 野田ガス(株) & & $\begin{array}{l}\text { 温水式液化石油 } \\
\text { ガス発生装置 } \\
\mathrm{NK} \mathrm{K} \text {-20-V M }\end{array}$ & 1 & ブタン & $4320 \mathrm{~kg} /$ 日 & 7200 & 7000 & $6 \mathrm{~A}$ & 47.12 \\
\hline 青梅ガス(株) & & $\begin{array}{l}\text { 温水式液化石油 } \\
\text { ガス発生装置 } \\
\mathrm{NK} \text { G }-60-V \mathrm{M}\end{array}$ & 1 & ブタン & $8400 \mathrm{~kg} /$ 日 & 14400 & 7000 & $6 \mathrm{~A}$ & 47. 12 \\
\hline
\end{tabular}




\begin{tabular}{|c|c|c|c|c|c|c|c|c|c|}
\hline 事業者名 & 工 場 名 & 装 置 名 & $\begin{array}{l}\text { 基 } \\
\text { 数 }\end{array}$ & 原 料 & 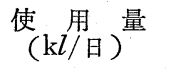 & $\begin{array}{l}\text { 能 力 } \\
\left(\mathrm{m}^{3} / \text { 日) }\right.\end{array}$ & $\begin{array}{l}\text { 供給 } \\
\text { 熱量 }\end{array}$ & $\begin{array}{l}\text { 燃焼 } \\
\text { 性 }\end{array}$ & $\begin{array}{l}\text { 建 設 } \\
\text { 年 月 }\end{array}$ \\
\hline 小松瓦斯(株） & & NG C -7 & 1 & ナフサ & 13.9 & 25000 & 3600 & $4 \mathrm{C}$ & 47. 10 \\
\hline 津島瓦斯（株） & 江南営業所 & B G & 1 & $\begin{array}{l}\text { ナフササ } \\
\mathrm{L} P \mathrm{PG}\end{array}$ & $\begin{array}{c}12.0 \mathrm{kl} / \text { 日 } \\
0.9 \mathrm{t} / \text { 日 }\end{array}$ & 25000 & 4500 & $5 \mathrm{~A}$ & 47. \\
\hline 金 沢 市 & 港 工 場 & $\mathrm{NGC}-7$ & 1 & ナフサ & 30.0 & 50000 & 3600 & $4 \mathrm{C}$ & 47.11 \\
\hline 丹後瓦斯(株) & $\begin{array}{l}\text { 都市 ガ } \text { 希 } \\
\text { 工場 }\end{array}$ & NRG & 1 & ナフサ & 15.0 & 23400 & 4500 & $5 \mathrm{~A}$ & 47. 12 \\
\hline 福＼cjkstart井＼cjkstart市 & & $\begin{array}{l}\text { 温水加温式気化 } \\
\text { 装置 }\end{array}$ & 1 & L P G & $7000 \mathrm{~kg} /$ 日 & 18000 & 4500 & $5 \mathrm{C}$ & 47. 10 \\
\hline 新宮ガス(株) & & $\begin{array}{l}\text { 温水式液化石油 } \\
\text { ガス発生装置 }\end{array}$ & 1 & L P G & $16800 \mathrm{~kg} /$ 日 & 28800 & 7000 & $6 \mathrm{~A}$ & 47. 9 \\
\hline 津山瓦斯(株) & & $\mathrm{OG}$ & 2 & $\begin{array}{l}\text { ナフササ } \\
\mathrm{L} P \mathrm{PG}\end{array}$ & $\begin{array}{l}14.3 \mathrm{k} l / \text { 日 } \\
16.5 \mathrm{t} / \text { 日 }\end{array}$ & 58000 & 5000 & $5 \mathrm{~A}$ & 47. 11 \\
\hline 広島ガス（株） & 阿賀工場 & $\mathrm{HG}$ & 1 & ナフサ & 60.0 & 80000 & 4500 & $6 \mathrm{C}$ & 47. 12 \\
\hline 宇 部 市 & & NG C -7 & 1 & ナフサ & 21.1 & 30000 & 4500 & $5 \mathrm{C}$ & 47. 11 \\
\hline 西部瓦斯（株） & $\begin{array}{l}\text { 長崎支社 } \\
\text { 時津 工場 }\end{array}$ & SM (二筒式) & 1 & ナフサ & 73.0 & 100000 & 4500 & $5 \mathrm{C}$ & 47. \\
\hline 佐＼cjkstart賀＼cjkstart市 & & NG C -7 & 1 & ナフサ & 21.0 & 30000 & 4500 & $5 \mathrm{C}$ & 47. 9 \\
\hline 宮崎瓦斯（株） & 宮崎営業所 & $\mathrm{OG}$ & 1 & ナフサ & 43.8 & 60000 & 4500 & $5 \mathrm{C}$ & 47. 12 \\
\hline 大分瓦斯(株) & $\begin{array}{l}\text { 大分営業所 } \\
\text { 東 I 場 }\end{array}$ & $\mathrm{TG}-\mathrm{PC}$ & 2 & ナフサ & 50.0 & 80000 & 4500 & $5 \mathrm{~A}$ & 47. 12 \\
\hline 筑紫瓦斯(株) & & B G & 1 & ナフサ & 13.0 & 20000 & 4500 & $5 \mathrm{~B}$ & 47.12 \\
\hline 日本瓦斯(株) & 吉野営業所 & $\begin{array}{l}\text { 温水式液化石油 } \\
\text { 洊発生装㯰 } \\
\mathrm{NK} \mathrm{K}-60-\mathrm{M}\end{array}$ & 1 & ブタン & $7200 \mathrm{~kg} /$ 日 & 14400 & 7000 & $6 \mathrm{~A}$ & 47.10 \\
\hline
\end{tabular}

スは17\%増で, その他ガスが $32 \%$ の増加となった。な お, 生産ガス中の構成比は石炭ガス $19.3 \%$, 石油系ガ ス45.8\%, 天然ガス $6.3 \%$ となっている。図 4-3 に年 別都市ガス原料別構成比を示し, 表 4-11 にガス工業 諸統計および前年との比較を示す。

3. 技術関係

東京瓦斯, 大阪瓦斯の両社は, 昭和47年 6 月 23 日ア メリカのガス会社 32 社が構成している天然ガス燃料電 池の実用化研究開発を推進する「ガスエネルギー変 換推進チーム（ターゲット）」に参加することになっ た。

ボイラーおよびガス直焚冷温水発生器について, 東 京瓦斯, 大阪瓦斯, 東邦瓦斯の 3 社合同によるガスボ イラー燃焼設備の共通安全基準を作製した

東京瓦斯，大阪瓦斯，東京電力の 3 社共同による， 世界最大のプロジェクトであるブルネイ産天然ガス導 入は，第 1 船が昭和 47 年 12 月大阪瓦斯泉北工場に 3.5 万 $\mathrm{t}$ が入港し, 続いて昭和 48 年 1 月東京瓦斯根岸工場 に 3.2 万 $\mathrm{t}$ が導入された。

東京瓦斯では, 新宿副都心計画に続いて昭和48年 1 月22日より成田ニュータウン地域冷暖房計画の一環と

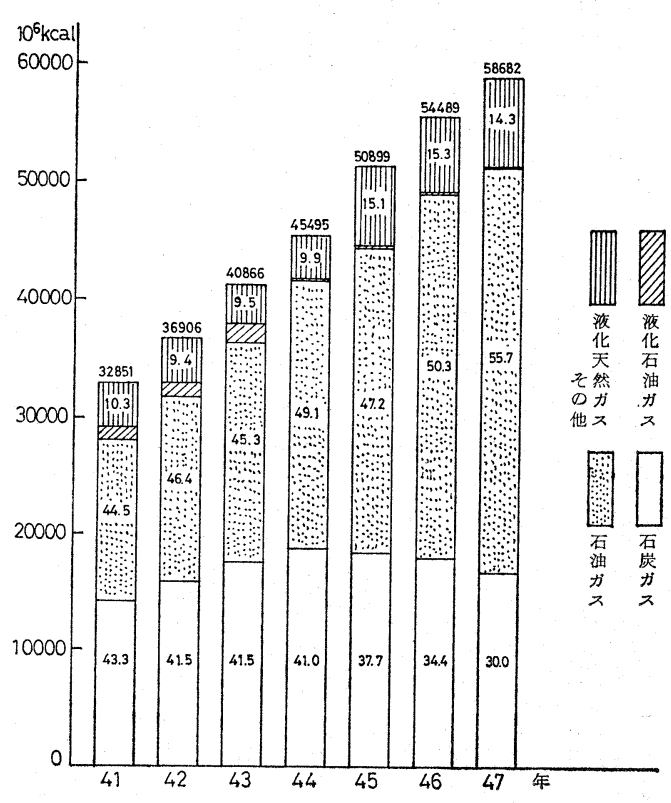

図 4-3 年別都市ガス原料別構成比

して成田ニュータウンセンタービルに本格的な供給を 


\section{表 4-11 昭和 45 47年ガス工業統計および前年との比較}

昭 和 45 年

\begin{tabular}{|c|c|c|c|c|c|c|c|c|c|c|}
\hline & & & & & & & & & & \\
\hline & 種 & $\begin{array}{l}\text { ガ } \text { ス 量 } \\
\left(10^{6} \mathrm{kcal}\right)\end{array}$ & $\begin{array}{l}\text { 文 } \\
\text { 垍 }\end{array}$ & & $0^{6}$ kcal) & $\begin{array}{l}\text { 対前年 } \\
\text { 動加率 }\end{array}$ & 表成 & $\begin{array}{l}\text { カj } \\
\left(10^{6}\right.\end{array}$ & 年 & t \\
\hline & 石炭系ガ ス & 2 & 100.1 & 4 & 4 & 93.3 & 22.1 & 361104 & 4.3 & 19. \\
\hline & 石油系ガ ス & 429 & 108 & 40.1 & 334 & 112.0 & 41.9 & 26858280 & 17. 6 & 45.8 \\
\hline & 天 然 ガ & 23597 & & & 3 & & 6.9 & 32 & 98.6 & 6. \\
\hline & その他 ガ ス & 54738 & 118.5 & 0.1 & 20 & 71 & 0.1 & 22 & & 0.1 \\
\hline & 計 & 3678 & 113.4 & .3 & 38663261 & 105.1 & 0 & 38 & 5 & 71.5 \\
\hline & (石炭系ガ ス & 756 & 10 & 3 & 38 & 107 & 12.3 & 630 & 3.4 & 10.7 \\
\hline & 石油系 ガ ス & 3640752 & 5 & & 42 & 125.0 & 8.4 & 309 & 120.6 & 9. \\
\hline & 天 然 ガ & 4162477 & 111.4 & O & 449 & 108. & 8. & 30 & & 8. \\
\hline & その他ガ ス & 36128 & 1 & 0.1 & 34 & 81. & 0 & 8 & & 0. \\
\hline & 小 計 & 13 & 10 & 7 & 23 & 112.1 & 29.0 & 85 & & 28.5 \\
\hline & 計 & 50899229 & 11 & 0 & 4 & 107 & 0 & 23 & 107.7 & 100.0 \\
\hline & 用 & 2850 & 11 & & $3166^{\prime}$ & 111.1 & 4 & 26 & & 65.9 \\
\hline & 業 & & 11 & & 61 & 106.5 & 18.8 & 883 & 9 & 18. 6 \\
\hline & 用 & & & & 58 & 103.9 & 10.3 & 827 & 107.4 & 10.2 \\
\hline & そ の 他 & 258 & & 5.8 & 3 & 10 & 5.5 & 234 & 104.2 & 5. \\
\hline & 計 & 44465262 & 114 & 0 & 48 & 10 & 0 & 70 & 5 & 100. \\
\hline & 庭 & 78 & 1 & & 10307345 & 107.6 & 94.1 & 30 & 0 & 94. \\
\hline & 用 & 0 & & & 490479 & 105.4 & 4.5 & 528131 & .7 & 4. \\
\hline & 工 & 53549 & & & & 10 & 0. & 61 & 2 & 0. \\
\hline & そ の 他 用 & 92022 & & & & 1 & & 45 & 1 & 0. \\
\hline & 計 & 10186489 & 108.0 & 0 & 1094 & 10 & 100.0 & 67 & 0 & 00. \\
\hline & 炭（t ） & 7 & 1 & - & 6682035 & 93.8 & - & 331 & $J$ & - \\
\hline & $\sqsupset-ク \pi(\mathrm{t})$ & 053 & & 一 & 46521 & 113.3 & - & 56144 & 120.7 & - \\
\hline & 原・重・軽 油（kl） & 1302405 & 10 & 一 & 1268 & 97 & - & 419 & 79.8 & - \\
\hline & 灯·揮 発 油 $(\mathrm{k} l)$ & 1545128 & 108 & - & 1799675 & 116.5 & - & 2298944 & 127.7 & - \\
\hline & 液化石油(1000kg) & 176301 & 113.4 & 一 & 222805 & 126.4 & - & 388659 & 174.4 & - \\
\hline & 天然ガス $\left(1000 m^{3}\right)$ & 484533 & 110.0 & - & - & - & 一 & - & - & - \\
\hline & $\mathrm{L} \quad \mathrm{N} \quad \mathrm{G}(\mathrm{t})$ & 50 & 11 & 一 & 247390 & 107.9 & - & 239985 & 97.0 & 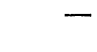 \\
\hline & 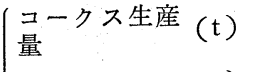 & 5145066 & 1 & - & - & - & - & - & - & \\
\hline & "I 販売量 $(\mathrm{t})$ & 5027816 & 10 & - & 4643855 & 92.4 & - & 4324539 & 93.1 & - \\
\hline & タール生産量 (t) & 528364 & & - & - & - & 一 & 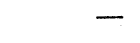 & . & - \\
\hline & " 販売量 (t) & 93 & 86.6 & - & 29975 & 53.5 & - & 21603 & 72.1 & \\
\hline
\end{tabular}

開始した。さらに同社は, 天然ガス転換計画が昭和 47 年 11 月にて 4.6 万件の転換完了, 昭和 48 年には 30 万件 を対象として（浦和, 川口, 草加など) 実施するが, 埼玉県は昭和48年をもって完了する予定である。

イ）豊洲工場に ICI 装置 $540 \mathrm{k} l /$ 日 74 万 $\mathrm{m}^{3}$ (5000 $\mathrm{kcal})$ 世界最大規模の設備を昭和 47 年 12 月に操業を開 始した。

ロ）大森工場に受入れたオフガススティームリフォ ーミングによる ORG 装置 22 万 $\mathrm{m}^{3}(5000 \mathrm{kcal})$ の稼 動を昭和 43 年 10 月より行なった。
大阪瓦斯では，泉北工場にプロセスコンピューター を採用した ICI 改質装置 62 万 $5000 \mathrm{~m}^{3} /$ 日, $4500 \mathrm{kcal}$ ×2） 2 系列を 12 月完成し，これにより今までに 4 系 列の設備が完了した。

東邦瓦斯では，STG 2 号 50 万 $\mathrm{m}^{3} /$ 日 (4500 kcal) が空見工場に昭和 47 年 10 月に稼動に入り，続いて 3 , 4 号機は昭和 48 年に完成する予定である。

製造関係については，東京瓦斯の DDCを使用した ICI 装置の自動運転開始 ${ }^{3}$, 従来の THT に替るオド メール Tの新付剂の開発 ${ }^{4)}$, 大阪瓦斯では排水中のシ 
アンの自動分析の開発 ${ }^{5)}$ ，旭川瓦斯 $\mathrm{P}-5$ ( 14 万 $\mathrm{m}^{3}$ /日， $3600 \mathrm{kcal})$ の発生装置の増設。

京葉瓦斯においては, 昭和 47 年 12 月 MRG (10万 $6000 \mathrm{~m}^{3} /$ 日， $6800 \mathrm{kcal}$ ) の稼動を行ない，仙台瓦斯む 同装置 $\left(14\right.$ 万 $4000 \mathrm{~m}^{3} /$ 日， $\left.5000 \mathrm{kcal}\right)$ を昭和 48 年 6 月 に完成の予定である。

NRG プラントは丹後瓦斯 ( 1 万5000 m³ $/$ 日， 7000 $\mathrm{kcal})$ が昭和 47 年末に試運転を完了, さらに NRG$\mathrm{CR}$ 型を千歳市 ( 2 万 $\mathrm{m}^{3}$ /日, $3600 \mathrm{kcal}$ ) も建設中で ある。

粲宮ガスでは，LNG，LPG によるサテライト方式 による中圧供給を昭和46年10月より開始した ${ }^{6)}$ 。

供給面では，東京瓦斯の中圧アングルガバナー7), $\mathrm{F} \cdot \mathrm{F}$ 方式を利用した新型暖房器8), 東京瓦斯, 大阪瓦 斯共同によるボイラー用大形バーナー9)，大阪瓦斯の ガス超高速ガスレンジ ${ }^{10)}$, 東邦瓦斯の S.E 継手 ${ }^{11)}$ どの開発が行なわれた。

日本瓦斯協会においては, 大気污染防止などの諸政 策に協力し，さらに合理化を図るためビルディング冷 暖房用熱源を重油より都市ガスに切り替えた（昭和 47 年 6 月)。

また，熱供給事業者が事業法の政省令，その他の問 題について検討を行なうため昭和 47 年 8 月に日本熱供 給事業協会が発足した。

ガス設備ユニット形式承認制度が昭和 48 年 1 月より 発足, 日本瓦斯協会内審查機関で形式承認されること になった。

\section{4. 諸外国の状況}

1. アメリカ

1971年にアメリカのガス事業は，パイプライン事業 を含めて販売量, 需要家において史上最高に達した。 伸び率は販売量において前年より $1.6 \%$ ，需要家数は 4300 万件近くまで増加し, 家庭用ガスは $2.2 \%$ 増で, 商業用ガスは， $3.7 \%$ の低下を示した。ガス販売量 は，全ガスの $57 \%$ を占めているが新規販売制限のため 若干低下した。

アメリカガス協会 統計 局の発表によると，1971年 1630億サームに達し，1995年までに2500万件増加し， 4510 億サーム $(1$ サーム $=2$ 万 $5210 \mathrm{kcal})$ に達する予 定である。

1971年のパイプラインおよび導管敷設 哩数は 2 万 6000 mile に達しこれにより全長 93 万 4700 mile とな った。

2. イギリス

1971年から1972年にわたって英ガス事業は著しい発
展を示し，1975年を最終年とする拡張計画をさらに前 進した。年間のガス販売量は前年に比し，20.1億サー ムの増加で合計 87.49 億サーム（前年67. 4 億サーム） となった。

なお，用途別販売は家庭用 $10.7 \%$ ，商業用 $13.1 \%$ ， 工業用 $80.1 \%$ の躍進を遂げた。天然ガスストレート供 給は, 全体の $87 \%$ に達し需要家は 600 万件となった。 なお，天然ガス液化プラントもグレンメイブスにおい て操業を開始し，さらにマンチェスター捛よび南ウェ ールズにも設立される予定である。

3. フランス

フランスのガス販売量は, この 25 年間に 7 倍に増加 し，1975年には 100 億 $\mathrm{m}^{3}$ まで達すると思われる。天 然ガスの転換は1978年までには完了する予定であり, 1971年末において天然ガスの直接供給を受けている需 要家は 400 万件に達した。1975年以降, ソ連の天然ガ スをフランスー供給する交渉が始められている。

\section{4. カナダ}

カナダの需要家数は1971年に 195 万件であり，その 5ち家庭用は 175 万件となっている。なお，国内エネ ルギー需要の $23.5 \%$ は, 天然ガスによって賄われてお り 1980年には $28 \%$ になる見込みである。

\section{5. ソ 連}

1971年の確認埋蔵量は, 12 兆 $\mathrm{m}^{3}$ に達した。埋蔵田 は主としてシベリア地方にあり，この原野を横断して ガス輸送するため口径 $1422 \mathrm{~mm}$ のものを建設中であ り, 将来は $2490 \mathrm{~mm}$ のものを計画している。1971年 の生産量は 2120 億 $\mathrm{m}^{3}$ と前年に比し, わずか $5 \%$ の上 昇にすぎなかった。

欧米では，イ）公害防止のための天然ガスによる污 物焼却方法, 焼却器の利用 ${ }^{12)}$, 口) 供給管の新しい漏 洩修理方法 “Gas Phase” シール法であらゆる管に適 する方法 ${ }^{13)}$ ，八）漏洩個所の発見や修理のためジョイ ントの位置を発見する方法の研究 ${ }^{14)}$, 二) 供給管とし てプラスチック管の増加の傾向 ${ }^{15)}$, などの文献が目立 った。

\section{文献*} $* 1972$

1）日本瓦斯協会誌，25，(7)，47

2) 同誌, 25, (7), 10

3) 同誌, 25, (7), 3

4) 同誌, 25, (7), 10

5) 同誌, 25, (7), 16

6) 同誌, $25,(5), 10$

7) 同誌, $25,(8), 46$

8) 同誌, 25, (6), 20

9) 同誌, 25, (6), 26

10) 同誌, $25,(6), 38$ 
11) 同誌, $\mathbf{2 5},(6), 49$

12) AGA Monthly, (1), 10

Industrial Gas, (11), 20

13) Gas, (6), 58

14) Gas World, (3), 25

15) Gas, (1), 44

\section{3 合成ガス製造の動向}

\section{1. 一般情 勢}

アンモニアの最大用途である窒素肥料は完全に国際 商品であり，需給は世界的な規模で決まり予測がむず かしい。昨年まで世界的な供給過剰により肥料業界の 見通しは暗く, 経営内容は当分悪化の一途をたどるか のように思われていたが, アメリカでは 4 月頃から需 要が伸びはじめ， 5 月期では前年同期の $12 \%$ 増加と需 要回復が本格化してきた ${ }^{1)}$ 。わが国でも硫安に始まる 一連のインドの肥料大量買付けが誘因となって需給の タイト化が表面化してきた。その後も輸出の伸びは大 きく, 現在アンモニア大形プラントはフル稼動してお り, やっと大形化のメリットを享受できる環境ができ たことになる。この需給関係の急速な変化の要因とし て，(1)ソ連のかんばつ, 暖冬, (2)連欧圏のかんばつ, (3)アメリカの旧設備のスクラップ化および天然ガス不 足による生産低下，(4)インドの大量肥料買付け，など が挙げられているが, 一方, 供給側での市況不安に対 する増設の延期, 生産調整, 不採算工場閉鎖が根本原 因といら意見 ${ }^{2)}$ のほか, 供給量の人為的操作でなく大 形化設備が需給のならし段階に到達したという意見 ${ }^{3)}$ などさまざまである。全世界の統計4)によれば1971肥 年では消費は $8 \%$ アップと過去の伸び率 $9 \%$ より落ち てきているが，2，3 年で供給過剰は解消されるとい われる5)。

肥料の輸出は，この 1 年で大きく状況が変わった。 7 月に行なわれたインド政府の尿素国際入札が FOB 61.88 ドルで落札し需給変化を示す材料として注目さ れた。インドは国内の食糧難を反映して, その後も肥 料の大量買付けを行なっている。中国への輸出交渉は 英ポンドの変動相場制採用のため一時中断したが, 元 建てポンド払いでまとまった。数量は前年より減った が需給タイト化による日本側の要請であり, 中国への 輸出依存度は若干低下することになろう。值段は FOB
ベースで硫安 $13 \%$ ，尿素 $11 \%$ と 7 年ぶりに前年を上回 った ${ }^{6)}$ 。今年に入ってからのインドとの尿素20万 $\mathrm{t}$ 商 談でも価格は上昇し C\&F 2 万 6700 円/ t であり ${ }^{7)}$, FOB では 2 万 2000 円 $/ \mathrm{t}$ 以上であろら。国内では 47 肥価格はあい変わらず下落したが，下げ幅はこの数年 拡大していたのに初めて縮小したのが注目される。な お46肥年までの生産, 輸出実績を表 4-12 に示す。

\section{表 4-12 尿素, 硫安の生産量および輸出依存度}

\begin{tabular}{|c|c|c|c|c|}
\hline & 尿 & 素 & 硫 & 安 \\
\hline 把＼cjkstart年 & $\begin{array}{l}\text { 生 産 } \\
\left(10^{3} \mathrm{t}\right)\end{array}$ & ${ }^{\text {輸 }}(\%)$ & 生 $\frac{\text { 産 }}{\left(10^{3}\right.}$ t $)$ & $\begin{array}{l}\text { 輸 } \% \text { 出 } \\
(\%)\end{array}$ \\
\hline 42 & 2084 & 69.2 & 2593 & 51.5 \\
\hline 43 & 2196 & 51.4 & 2414 & 45.8 \\
\hline 44 & 2321 & 74.3 & 2287 & 56.5 \\
\hline 45 & 2372 & 89.0 & 2106 & 58.5 \\
\hline 46 & 2522 & 71.0 & 1926 & 68.0 \\
\hline
\end{tabular}

肥料要覧 1973年版

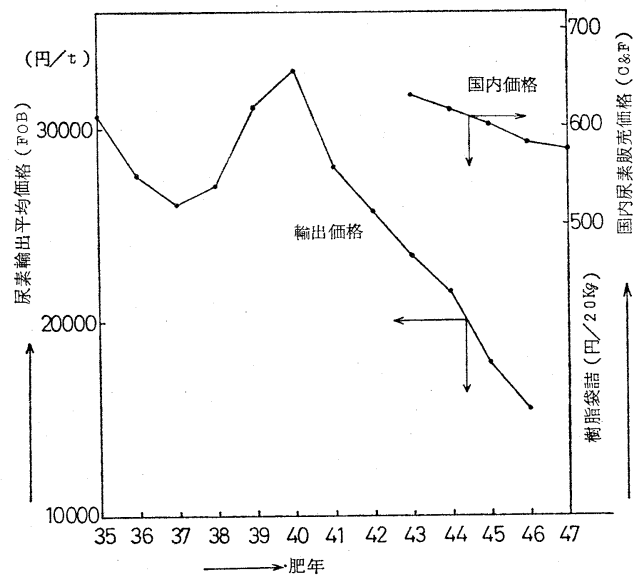

図 4-4 尿素の輸出および国内価格の推移 （肥料要覧 1973年版）

アンモニアの生産能力は昨年 2 月の宇部アンモニア の営業運転開始による第 2 次大形化計画の完了後, ほ とんど変化はない。47年 4 月では 461万 $\mathrm{t} /$ 年 と公表 されているが，一部メーカーの休止により443万 $\mathrm{t} /$ 年 と修正されている。大形プラントの操業は鹿島アンモ ニアがコンプレッサーなどの不調で 47 年 11 月まで長期 閒低操業を続けた以外はおおおむね順調である。46肥年 では 345 万 t 年 の生産をし, 操業率は $81.4 \%$ といわ れる ${ }^{8)}$ 。 47 肥年に入り $7 \sim 11$ 月の平均操業度が $82.4 \%$ と定期修理の影響が出ているが，需要を満たすために は今後 $96 \%$ の操業が要求されている。 


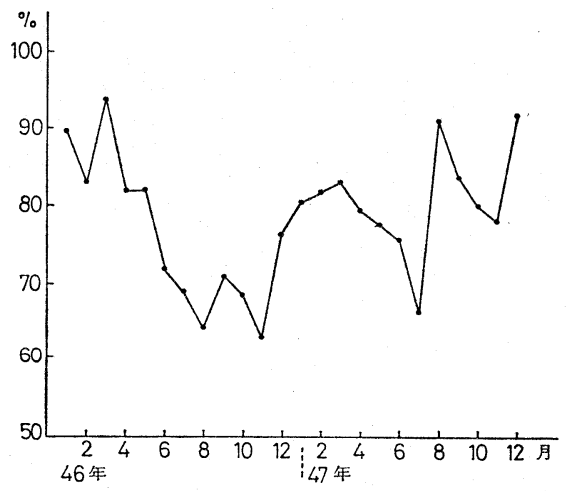

図 4-5 アンモニアプラント操業率 （化学工業統計月報）
アンモニアの用途は肥料用，工業用に二分され， 45 肥年で初めて工業用が肥料用を追い越したが，46肥年 では再び肥料用に抑えられた。これは合繊の不況が直 接的な原因である。しかし47肥年に入り，経済全般の 立直りから工業用の投入量が増加を始め， $7 \sim 11$ 月間 では月平均で肥料用を 1 万 $4000 \mathrm{t}$ 上回っている。肥料 輸出を重点に考えざるをえないアンモニア業界にあっ ては,このように回復してきた工業用の需要に対する 供給力が心配されている9 。

産業構造審議会化学肥料分科会が開かれ, 長期需要 見通し, 輸出対策, 企業体質の強化などにつき検討さ れた。長期的には発展途上国の自給化の進展による輸 出減, 内需の停滞が予想され, アンモニア工業の体質 改善を急ぐよう強調された ${ }^{10)}$ 。急速な需給タイト化の

表 4-13 ン モニア 用途別消費

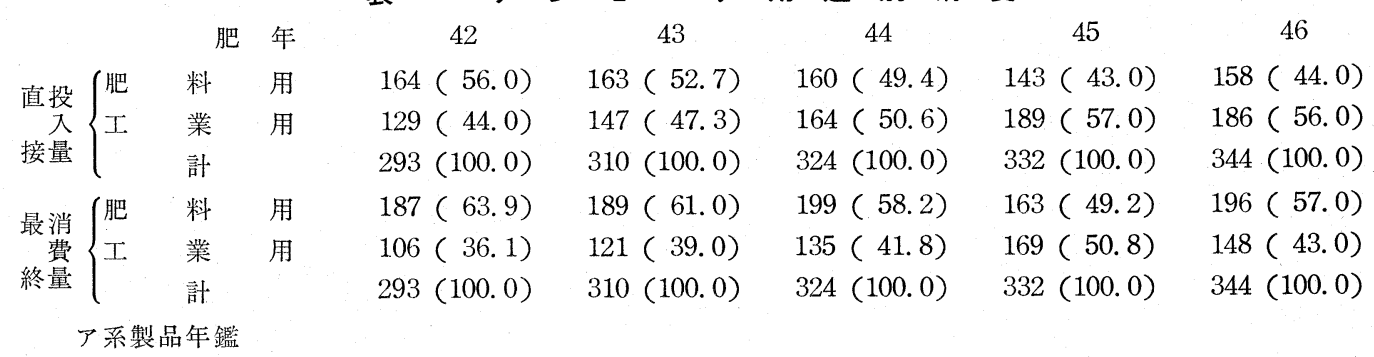

底には依然としてアンモニア工業の本質的問題が未解 決のまま残されているといえよう。

メタノールは合板, DMT などの需要増大にともな い, 最近10年閒の平均伸び率は米国 $9 \%$, 日本 $17 \%$, ヨーロッパ10\%と順調に伸びている。全世界のメタ， ールの需要は約 800 万 t で伸び率を $10 \%$ と見ると，年 間80万 t の伸びとなり，全世界で 1000 t / 日 の大形プ ラントが 1 年間に新しく 3 基操業すればよいことにな る。大規模プラントの供給力に対してマーケットが相 対的に小さいことがアンモニアの場合と非常に異なる 点である ${ }^{11)}$ 。こような事情で昨年西日本メタノール の稼動により供給力過剰が心配され, 輸出も期待薄と いうことで東西両センターは $20 \%$ 自主減産を行なって きた。昨年後半に入り，まずアメリカのメタノール市 況がハウジングブームで好転しはじめ，わが国も景気 立直りにつれ構造材, 家電用のホルマリンが伸びメタ ノール需要が増大した。一方, 供給は 6 月の海員スト の長期化でオーストラリア，中近東からの LPG 入手 が途絶え， 6 月定修から 7 月20日までストップした。 問題になっていた東日本メタノールのコンプレッサー の不調は10月定修時に取り換え, その後 $100 \%$ 稼動が
可能になった。両センターの本格操業にともない，小 形プラントのスクラップ化も進み，11月の新日鉄戸畑 (130 t /日) のストップにより，旧設備のスクラップ 化は完了した ${ }^{12)}$ 。

生産実績を月別にみると10万 $\mathrm{t}$ をオーバーしたのは 4 力月で生産のバラツキが大きい。これは大形設備の 運転の不調, 定修後の再スタートの不順なども原因で あり，47年度の生産は前年の $4.2 \%$ アップといら伸び 率で近年の最低となった。

\section{表 4-14 メタノール需給推移}

(単位 $: 14^{4} \mathrm{t} /$ 年)

\begin{tabular}{|c|c|c|c|c|}
\hline 暦年 & 内 需 & 輸 出 & 生 産 & 能 力 \\
\hline 45 & 86 & 8 & 94 & 108 \\
\hline 46 & 94 & 9 & 103 & 120 \\
\hline 47 & 102.5 & 5.5 & 108 & 127 \\
\hline 48 & (118) & (6) & (124) & 127 \\
\hline
\end{tabular}

需給タイト化のため第 3 センターである鹿島メタノ 一ル計画 $(800 \mathrm{t} /$ 日, 三菱瓦斯化学, 信越化学, 日本 化成, 協和発酵の共同出資）が認可され, ICI の低圧 法で48年後半より生産開始することになった。 
需給均衝にもかかわらず, 価格は軟化していたが, 国際価格に比べても割安であり, 採算割れの状態とい うことで大手メーカーの值上げ方針が打ち出されてい $ろ^{13)}$ 。

輸出は後進国の自給率が進み期待が持てなかったが アメリカが原料不足, 大形プラントのトラブルや旧設 備のスクラップ化などで供給がひっ迫し，ヨーロッパ でもアンモニアへの装置転換などで世界的に玉不足と なった。アメリカからわが国への輸入引合いもあった が供給能力の点で見送り之なった ${ }^{14)}$ 。輸出は中国への 1 万 $3000 \mathrm{t}$ ，オーストラリア ICI 1 万 $5000 \mathrm{t}$ が大 ロである。

メタノールの用途は依然としてホルマリンが大半を 占め, DMT が10\%台, 医薬・農業，合成樹脂と続い ているが，将来, メタノールの需要を飛躍的に拡大す る可能性のある幾つかの新規用途が胎動している。

その 1 つはメタノールの無公害燃料化で, 海外の安 い天然ガスでメタノールを製造し, タンカーで消費地 に輸送しょうとするものである。LNG が液化, 低温 タンカーでの輸送, 再ガス化といら処理が必要なのに 比ベ,メタノールは従来のタンカーで輸送し, そのま ま燃料として使える利点がある。Selas 社の試算では 北アフリカからアメリカ東部、輸送する場合, メタ ノールが 0.84 円 $/ 10^{3} \mathrm{kcal}$, LNG が 0.87 円 $/ 10^{3} \mathrm{kcal}$ といら ${ }^{15)}$ 。また, Chem. System 社は 3000 5000 海 里以上の輸送なら LNG より安価と試算結果を発表し ている(16)。Vulcan 社ではニューオーリンズの発電所 でメタノール燃料化の実験を行ない, 燃焼性, 無公害 性の点で有望なエネルギー源と発表している ${ }^{17) 。 わ か ゙ ~}$ 国でも電力, 化学会社および商社で検討を開始してい る。

ガソリンにメタノールを配合すると自動車排気中の 炭化水素, $\mathrm{CO}$ および $\mathrm{NO}_{x}$ が減少するとともにノッ キング防止に役立ち, テトラエチル鉛の添加も不要に なるといわれる18)。メタノールを $20 \%$ 添加するとして も, 日本で 600 万 $\mathrm{k} l /$ 年 となり, 現在の生産能力の 3.8 倍にもなる。

メタノールを下水処理に利用する研究が進められて いる。下水中の全窒素を硝酸塩に変えた後, 嫌気性バ クテリアを含むスラッジと接触させ, 同時にメタノー ルを添加するもので，メタノールはバクテリアが硝酸 塩を気体窒素と炭酸ガスに転化させるときのカーボン 源に使われる。アメリカでは1976年に約45万 t , 1985 年に 135 万 $\mathrm{t}$ のメタールがこのために使われると推 測されている ${ }^{19)}$ 。
このほか, メタノールから合成たん白の製造技術を ICI が確立し， 3 年後に企業化すると伝えられてい る ${ }^{20)}$ 。わが国では厚生省などでの 3 年にわたる検討結 果が安全性に問題なしといらものであったが，その 後, 鐘化および大日本インキが国民的同意が得られる まで企業化を延期すると発表した。

このような大形の新規用途が実現したならばメタノ ールはエチレン，アンモニアのごとき大型商品になる とともにメタノール業界は体制, 体質とも本質的な変 換を余儀なくされるであろう。

\section{2. 合成ガス原料}

合成ガス原料の変遷はいわゆるエネルギー革命の進 展と同じ道を歩んできた。エネルギーコストの変化が 原料変化につながり，しかもエネルギー産業と比較的 協調的な関係で原料変遷が行なわれてきた。最近に至 り,このような関係を抜本的に変える要因が急速に表 面化してきておう，合成ガス原料の将来に大きな波紋 を投げかけている。それは,

(1) 燃料無公害化の影響

（2）エネルギー危機およびエネルギーコスト上昇

燃料の無公害化の中心は低硫黄化であり, その手段 として重油の水添脱硫，排煙脱硫があるが脱硫率の低 い点, 装置信頼性, 脱硫副産物の処理などの点で, 急 速な低硫黄化要請にこたえるまでに至っていない。そ こで電力, 鉄鋼などのエネルギー大量消費産業が低硫 黄燃料でもあるナフサ, 天然ガス, LPG の確保にの り出し, 化学産業と原料問題で真っ向から対立してき た。化学産業の原料分がエネルギー産業の $10 \%$ 程度で あること，エネルギー産業のエネルギーコストでは化 学製品の国際競争に勝てない点を子まえて原料問題の 展開が要求されているわけである。

イラク政府がイラク石油を昨年の 6 月に国有化した のを初め， 8 月にはイランがアバダン製油所を国有化 し， OPEC ペルシア湾諸国がメジャーへの経営参加 を獲得し, 数年後には $51 \%$ まで取得可能となった。こ のような産油国の一連の動きは民族意識のほかに全世 界的なエネルギー危機観が基調にある。テヘラン協定 による原油の毎年の值上げおよび経営参加にともなう メジャー利益損失分の補填としての值上げなどで，平 均 400 円 $/ \mathrm{k} l$ の值上げとなっている ${ }^{21)}$ これらの值上 げは直接, 合成ガス原料の值上げにつながり, 価格調 整の交渉は一般と厳しくなってきた。

このような安定価格原料の長期的確保の困難さは, わが国ばかりでなくアメリカに掠いても，天然ガスを 筆頭に問題化しており，とくに化学産業は原料確保に 
腐心している ${ }^{22)}$ ここような中で近日中に発表が予定 されているニクソン大統領のエネルギー教書に対し各 国とも増々エネルギー危機観を深めている現状であ る。

ナフサ原料は宇部アンモニア（46年 2 月）により増 加しているが，構成比では前年とほとんど差がない。 アンモニア原料として47年度は 160 万 $\mathrm{k} l$, メタノール 原料として $18 万 \mathrm{k} l$ が使われ，全ナフサ量から見れば 依然として数\%にすぎない。

\section{表 4-15 ガス源別アンモニア能力} (47年 4 月 1 日)

\begin{tabular}{|c|c|}
\hline 力 & $\begin{array}{c}\text { 百 分 率 } \\
(\%){ }^{-1}\end{array}$ \\
\hline 8 & 0.2 \\
\hline 360 & 7.8 \\
\hline 2009 & 43. 6 \\
\hline 1016 & 22.0 \\
\hline 391 & 8.5 \\
\hline 100 & 2.2 \\
\hline 727 & 15.7 \\
\hline 4611 & 100.0 \\
\hline
\end{tabular}

肥料要覧 1973年版

電力および鉄鋼のナフサ生だき計画によると 48 年 300 万 $\mathrm{k} l, 49$ 年 800 万 $\mathrm{k} l, 50$ 年 1100 万 $\mathrm{k} l$ となってお り，国内情勢でのナフサ得率アップとリターンナフ サ，それに軽灯油などを混合した新然料で賄い，48年 は生だき用ナフサの輸入はせず，49年，50年にそれぞ れ， 300 万 $\mathrm{k} l$ の輸入を認めることになった ${ }^{23)}$ このよ らなナフサ生だきに対し, 石油化学協会は生だきを極 力圧縮すること，原料用と燃料用の価格を区別するこ となどを通産省に要望している。ナフサ価格は原油の 值上げおよびナフサ需要の増大で，47年10 12月期で 300 円 $/ \mathrm{k} l, 48$ 年 1 月からはさらに 400 円 $/ \mathrm{k} l$ の值上げ を石油業界が提示し, 各社との接衝が行なわれてい る $^{24)}$ 。この 700 円 $/ \mathrm{k} l$ の值上げが成立すると, 7300 円 $/ \mathrm{k} l$ 程度になる模様でヨーロッパの4000 5000円 $/ \mathrm{k} l$ に比べ割高な原料となる。都市ガス用は 8100 円 $/ \mathrm{k} l$ を 提示しており，化学原料用の值上げのはねかえりが心 配される。アメリカの天然ガス不足から SNG の製造 計画が数多く発表されており, ナフサの海外からの輸 入が 1500 万 $\mathrm{k} l$ 程度になろうとナフサ需給の影響が心 配されている。

天然ガスは採取による地盤沈下が問題化しており， 化学原料用は前年とほとんど変わっていない。海外の
天然ガス開発への参加が活発化してお゙り，ソ連のサ八 リン天然ガスへ調查団が現地に赴いたほか, ヤクーツ ク天然ガス開発を住友商事がエルパソ社と共同して行 なら計画がある。三井物産など 4 社はオーストラリア の天然ガス採鉱利権を落札し, 日商岩井がカリマンタ ン（インドネシア）の天然ガス開発計画を発表してい る。ブルネイからの LNG は昨年 12 月に第一船が入津 し大阪瓦斯のプラントが稼動した。一方, 伊藤忠が計 画中だったイランからの LNG 輸入は ICF 1.0 ドル/ MMBTU (1.22円 $/ 10^{3} \mathrm{kcal}$ ) を切れず，事実上放棄さ れた。LNG はコストの点で前年以上に魅力を失いつ つあるようである。米国のアンモニア, メタノールの 原料は大部分が天然ガスであり，ガス不足のため，47 年後半で 70 ドル/MMBTU，1980年までに 1.0 ドル/ MMBTU になるとみられ, ナフサへの原料転換も考 えられているが，そのためには投資コストの $10 \sim 20 \%$ が必要で，また生産量は $20 \%$ 低下するといわれる ${ }^{25) 。 ~}$

LPG は昨年 2 月西日本メタノールの稼動後, 変化 していない。LPG の全需要は47年度は 900万 $\mathrm{t}$ と推 定され, 家庭用・業務用が $45 \%$, 工業用, 自動車用に 続いて化学原料用が $14 \%$ である。供給は輸入が初めて 47年度において国内生産を上回る見通しである ${ }^{26)}$ 。鉄 鋼での然料用としての使用が本年度で50万 $\mathrm{t}$ が予想さ れている。

公害燃料として嫌われている重質油および資源的に 豊富な石炭が新たに原料として浮び上がってきてい る。石炭のガス化は米英で精力的に研究開発されてお り，直接の狙いは SNG の製造であるが，化学原料に も使えるものなので注目に值する。

将来のエネルギーとして水素が, 経済的にも無公害 という点からも有望として主にアメリカで活発な検討 がなされている。 $\mathrm{H}_{2}$ 製造は原子力エネルギーによる 電気分解や水の直接熱分解などが挙げられているが, 経済的になるのは $\mathrm{H}_{2}$ 利用システムにある ${ }^{27) 。 20 〜 30 ~}$ 年先の実現化が期待されているが，そうなれば合成ガ ス原料問題も一変することになる。

\section{3. 合成ガス製造技術}

1. スチームリフォーミング

既存プロセスの改良に大きな進歩は見当たらない。 軽質油から SNG 製造の計画が主にアメリカで活発で ある ${ }^{28)}$ 。わが国でも日揮一大阪瓦斯共同開発による MRG プロセスが京葉瓦斯に建設された。

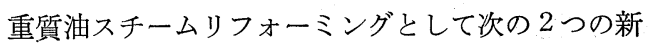
プロセスの開発が進められている。

その 1 つ Segas プロセスで, 無触媒でガス化す 
るもので 5 万 $\mathrm{ft}^{3} / \mathrm{hr}$ のパイロット建設中といら ${ }^{29)}$ 。東 京ガスと東洋エンジニアリングは触媒で重質油をガス 化し SNG 製造を目的とした共同研究を開始し，本年 5 月にテストプラント完成の予定。

2. 部分酸化

宇部興産は既設のテキサコ法アンモニアプラントを 原油から減圧残油に切り換えるための装置改良を行な っていたが，昨年 7 月に本格運転に入った ${ }^{31)} 。$

宇部のガス化脱硫プロセスは工業化試験の段階に入 り, 重質油 $250 \mathrm{t} /$ 日 処理のプラントを 14 億円で建 設, 脱硫パートはカタカーブプロセスと IFP プロセ スの組合せを採用 ${ }^{32)}$ 。

重質油をコーキングプロセスにかけ，軽質化し，塔 底からのカーボンを空気で部分酸化しガス化するフレ キシコーキングプロセスが発表された。東亜石油で 49 年末完成を目標に建設に着手した ${ }^{33)}$ 。

3. 合成ガス精製

COG 脱硫に大阪瓦斯が開発したフマックス法の最 初のプラントが住金化工に完成。COG 中のアンモニ アで $\mathrm{H}_{2} \mathrm{~S}$ を除去し， シアンはロダックス法で除去す るもので, 廃水中のロダン塩を燃焼処理して COD 解 消を行ならコンパックス法も合わせて開発 ${ }^{34)}$ 。

このほか, COG 脱硫プロセスとして実績のある東 京ガスのタカハックス法および最近開発された三菱化 成および三菱化工機のダイアモックスなどに海外から の引合いが多い。アメリカの石炭ガス化プロセスへの 採用検討もその一因である。

\section{4. その他の技術開発}

UCC の Linde Div. でモレキュラーシーブによる $\mathrm{O}_{2}$ 分離プロセスが完成。Pressure-swing adsorption と称する 1 80t/日 の $\mathrm{O}_{2}$ 製造プロセスで, 空気の加 圧, $\mathrm{N}_{2}$ 吸収, 減圧による $\mathrm{O}_{2}$ の回収, 吸着ガスのパ 一ジの工程からなり, 装置は $3 \sim 4$ 床で純度は $90 \%$ 以 上, 運転のフレキシビリティーに富み, 電力消費は $0.6 \mathrm{kWh} / \mathrm{m}^{3} \mathrm{O}_{2}{ }^{35)}$ 。

然料ガスからの $\mathrm{H}_{2}$ 分離プロセスとして Sepco 社 が “Seperane” といら分離用膜を開発, 90\%以上回収 し，純度は $96 \%$ の $\mathrm{H}_{2}$ が得られる ${ }^{36)}$ 。同様に帝人はナ イロン中空糸で水素回収を行なら方法を開発し実用化 の試験を行なっている ${ }^{37)}$ 。

回転機器の破損早期発見のための高周波振動分析技 術がアメリカで開発され，メタノール用プログラムが 完成した ${ }^{38)}$ 。

無人運転のできる小形水素プラントをアメリカから の技術提携でガスエンジニアリング社が完成。ブタン
スチームリフォーミングで能力は $100 \sim 2000 \mathrm{~m}^{3} / \mathrm{hr}$, コストは 20 円 $/ \mathrm{Nm}^{3}$ 程度といわれる ${ }^{39)}$ 。

文 $* 19 ? 2$

1) C.W., 7. 12, 33

2) 山中良一, 化学経済, 1972, (11), 18

3）化学工業日報, 9. 5

4) C.A., 11. 17, 20

5) $C \& E N, 9.18,10$

6）化学工業日報, 9. 5

7) 同誌, 2. 10

8) 同誌，9.12

9) 同誌, 2. 15

10) 同誌, 9. 10

11）小林公雄, アンモニアと工業，25，(4)，24

12) 石油化学新聞, 11. 13

13）化学工業日報, 48. 2. 3

14) 同誌, 7. 2

15) C.W., 7. 12, 35

16) ibid., 11. 29, 35

17) ibid., 11. 22, 64

18）山本為親, 化学経済, 1972，(12)，10

19) C.W., 7. 19, 35

20）化学工業日報，48，2. 18

21) 同誌, 48. 1. 14

22) $C \& E N, 11.13,24$

23）化学工業日報，11. 15

24) 同誌, 48. 1. 17

25) C.W., 9. 20, 30

26) 吉田稔, 石油と石油化学, 17, (2), 53

27) $C \& E N, 4.17,34$

28) $C . W ., 6.7,39$

29) $C \& E N, 8.7,25$

30）化学工業日報, 48. 2.7

31) 同誌, 7. 27

32) 石油化学新聞, 6. 5

33）化学工業日報, 9. 15

34) 同誌, 48. 1. 7

35) Chem. Eng., 10. 16, 88

36) C. W., 7. 19, 33

37）化学工業日報, 11. 18

38) C.W., 7. 19, 32

39）化学工業日報，48. 1. 12

\section{4 液化石油ガスの動向}

昭和 47 年度のわが国の液化石油ガス（ＬＰガス）消 費量は 872 万 t であったが, 昭和 49 年度には 1000 万 $\mathrm{t}$ を突破する市場が実現するものと予測されており，こ のような大規模な需要をもつ国はここ当分, アメリカ 
と日本の 2 国だけとなる状態が続くものと思われる。

このようにL P ガスが急速に発展した理由は, (1)戦 後の石油生産力が急速に拡大し, それにともなって L Pガスの供給力が確立されたこと, (2)高カロリー, 軽 便であること，(3)ネルギー革命の波にのったこと， (4)国民生活が急速に向上する時代の要請にマッチした こと，などがその主なものといえよう。
さらに最近では，(5) L P ガスが無公害然料としての 特性に優れている，という点が時代の脚光を浴びてお り, 公害防止の時代ともいわれる1970年代後半におい て，新しい局面を迎える方向に向かっている。

ちなみに, 昭和 31 年以降の需給バランスをみると表 4-16のとおりである。

昭和38年頃までは家庭業務用の需要がほとんどであ

表 4-16 昭和 31 46 年度 LP ガス需給バランス

(単位 : $1000 \mathrm{t}$ )

部門
年度

ったが，その後，供給力の増大と L P ガスの利用技術 の進歩などによって，自動車用の本格的な利用のほ か, 工業用その他の需要分野も開拓されはじめた。

昭和 48 年度の需要構成比をみると家庭業務用 $52 \%$, 工業用 $16 \%$, 自動車用 $25 \%$, その他 $7 \%$ であり, この あたりから，それまでの家庭業務用中心の需要構造か ら, 家庭業務以外の需要の増加がめだつようになって いる。さらに昭和 47 年度現在では, 家庭業務用は $40 \%$ 台になっている。

L P ガスは，世界的にみても家庭用然料としての利 用が中心となっているが，今後における需要増加の大 きな要因として，とくに注目す心゙きは，一般工業用や 鉄鋼業向けなど, 公害対策上からの特殊大口工業用の 著しい増加が見込まれる点であろう。

\section{1. 需要の実態}

(1) 家庭業務用

昭和 47 年度の家庭業務用は 417 万 $9000 \mathrm{t}$ （主として プロパン) で, 対前年度比 55 万 $8000 \mathrm{t}$ の増加で, 需要
構成比は $47.9 \%$ となっている (図 4-6 参照)。すなわ ち, 現在, 家庭業務用は総需要の約 $1 / 2$ にあたる状態 であり, 家庭用: 業務用の比率はお括むね $8: 2$ であ る。

最近における需要増加の要因は, 需要家件数の増加

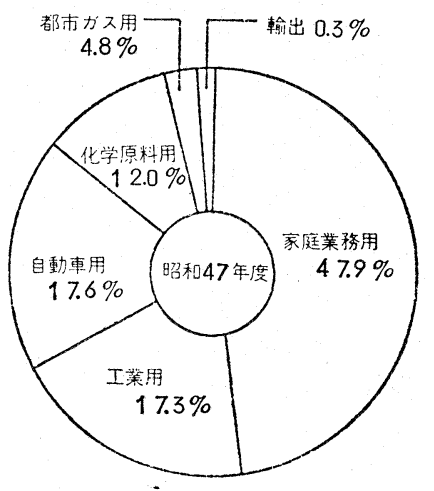

図 4-6 昭和47年度 LP ガス需要構成比 
よりも 1 家庭当りの単位消費量の増加にあるとされて いる。

家庭業務用の利用形態をみると，現在では炊飯用の ウエイトが高く, 給湯用, 暖房用などの利用が拡大さ れつつある状況で, 1 世帯当りの月間消費量は46年度 で $16 \mathrm{~kg}$ である。これは昭和 40 年度の $9 \mathrm{~kg}$ からする と, 毎年 $1 \mathrm{~kg}$ の水準の増加となっている。

また, これまで家庭用の L P ガスの配達には $10 \mathrm{~kg}$ 容器が主として用いられてきたが，消費量の増大にと もない容器の大形化が目だち, $20 \mathrm{~kg}, 50 \mathrm{~kg}$ などの中 形, 大形容器への転換が急速に進められている状況で ある。

\section{(2) 工 業用}

L P ガスの工業用需要は昭和47年度で 151 万（主 としてブタン) となり, 大幅な増加を示している。

工業用需要増大の要因は，L P ガスの無公害燃料と しての優位性によるものである。

最近, 鉄鋼業界や電力業界などが, L P ガスの無公 害然料としての使用を本格化させる動きを示している ように, 工業用分野における L P ガスは, すでに単な る特殊然料としての利用の域を脱し, 重油などから転 換する大量消費燃料としてその採用が進められる段階 に達している。

従来の工業用の分野においては, 製品に与える好影 響とそれがもたらす経済性, 合理性などが普及・浸透 の原動力となってきたのであるが, ここへきて, 公害 規制という社会環境の変化が, 新しい局面として L P ガス伸長の転換期を到来させている。ちなみに L P ガ スの工業用の利用形態を示すと表 4-17 のとおりであ る。

また，部門別需要の中で今後とも著しい伸びを示す とみられるのは, 工業用燃料と原料用需要であるが,

\section{表 4-17 LP ガスの工業用利用形態}

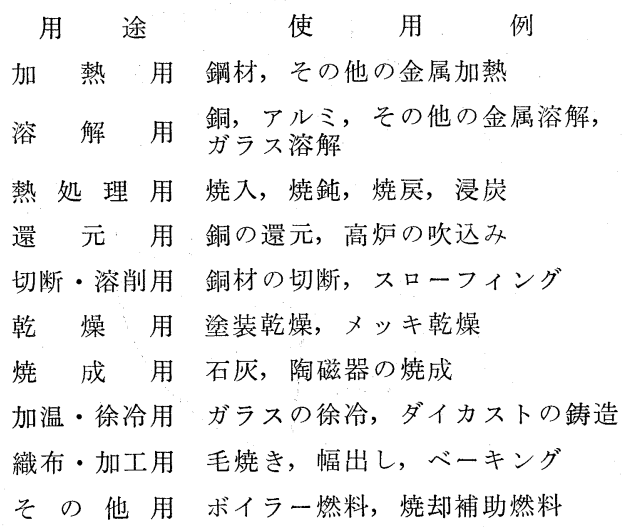

とくに工業用は過去 5 年間に 3 倍の伸びを示してお り，とくに46，47年度では一般経済が不況であるにも かかわらず大幅な増加を示したのである。

従来, 燃料として都市ガス, 重油などを使用してい た分野でも L P ガスは単に経済性のみでなく, その品 質特性 (不純分が少ない, カロリ一が高い, サルファ 一がない）から飛躍的に増加してきたのであるが，と くに現在では都市における公害規制の強化による“低 硫黄化” への要請が強まって, 重油からの転換があい 次いでいる。

今後の工業用については, 公害対策上, 競合燃料と の経済性いかんによって新規需要の開発につながる面 もありとくにブタンに対する評価が高まりつつある ので, 需要の大幅増加が期街されいる。この工業用 における L P ガスについての特性を要約すると表4-18 のとおりである。

\section{表 4-18 LP ガスの特性}

1. 硫黄分がほ 硫黄分は $0.005 \%$ 以下で, 公害 とんどない防止, 環境保全に役立つ

2. 発熱量が高 発熱量は $23000 \sim 29000 \mathrm{kcal} / \mathrm{Nm}^{3}$ 発熱量か高 と高く燃焼効率がよく, 作業能 い、率が向上する

3. 組成が均一炉内温度や需囲気調整が容易 で不純物がで, 製品の仕上りに影響をもた

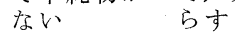

4. 燃焼性がよ 燃焼性が良いので, 自動化, 省 瑨性がよ役立つ

5. 入手性が良 LPガスは，全国に供給基地が い手性が长 あるので, どこでも安定的に入

6. 経 済 的 無公害燃料として他燃料に比べ

(3) 自動車用

現在 20 万台のタクシーに利用される自動車用の需要 は昭和 45 年度早々の課税額の引上げによって, 需要面 での影響が現われる可能性があったが，実際にはその 後も一応順調な伸長を示し，昭和 47 年度は 153 万 7000 $\mathrm{t}$ (主としてブタン) の実績となり, 全需要量に占め る比率は $17.6 \%$ となり, 工業用にほとんど追いつかれ てはいるものの, ともかく第 2 位の需要分野の面目を 保っている。

しかしながら, 最近の動向は, タクシー料金の值上 げ，タクシー運転手の不足, 交通渋滞の激化, 個人夕 クシーの増加などにより, 従来とは異なった動きを示 しており，昭和 45 年度までのスムーズな伸長に比べる と, 昭和 46 年度以降の伸びは, 需要条件の変化から鈍 化傾向にあることは否めない。

さらに今後の問題として, 公害規制の強化にともな 
う排気ガス規制強化の動向がある。

自動車の過密度が高いといわれるわが国において も, 自動車保有台数の増加にともない規制の基準が厳 しくなることが予想されている。昭和 50 年度の規制目 標は, アメリカの基準值に匹敵するものになるだろう ともいわれている。

(4) 都市ガス用

L P ガスが都市ガス用に消費される形態には従来よ り, 一般コールガスの増熱材とブタンエアーダイリュ 一ト方式での L P ガスによる都市ガス供給の 2 つのケ 一スがあるが， L P ガスの需要（主としてブタン）の 面からは昭和 47 年度の 41 万 $8000 \mathrm{t}$ 需要から昭和 52 年度 57 万 $3000 \mathrm{t}$ へと推移することが見込まれる程度で, 数 量的には増加を続けていくものの, シェアの点からは 大きな変化は起こらないことが予測されている。

最近では, 都市ガス用の LNG 導入が脚光を浴びて いるが，LNG は大規模な消費単位をもたなければ技 術・経済の両面からその消化が困難である。また, 今 後の LNG は低廉なものとは限らず, むしろ高騰化傾 向もみられる。このような状況からL P ガスの利用も 従来どおり漸増傾向を示しているのが実情である。

(5) 化学原料用

化学原料用の需要は昭和 47 年度は 104 万 $5000 \mathrm{t}$ （主 としてブタン，一部プロパン）の実績をもつに至っ た。

長期にわたってみた場合，L P ガス（主としてブタ
ン）を原料とする化学工場の稼動が続々と計画されて おり， 5 年後には現在より 2 倍程度の需要規模に達す るものとみられている。

現在, L Pガスは SBR 原料, IPA 原料, アンモ ニア原料, メタノール原料などに消費されているが, 将来の化学品需要の増加とともに, アンモニア, メタ ノール原料を中心に, 大幅な伸びが期待されるところ となっている。

(6) 輸出

L P ガスの輸出需要 (主としてプロパン) は, 長期 的には東南アジアへの輸出が行なわれる計画もある が, 現在の輸出は台湾, 香港向けのものである。

しかし最近は, 世界的にも資源不足の状況であり, 輸出の大幅な伸びは考えられない。

以上のように, 需要全般としては, L P ガスは, 従 来どおり家庭業務用の需要を中心に, 環境改善時代の 幕あけとともに新しく無公害燃料としての工業用需要 を伸長させ, また, 自動車用, 化学原料用の需要増を 背景に, 将来に向かってますますエネルギーとしての 貴重性を高め, 国民生活における重要な役割を果しつ つ, 安定成長を続けることが想定されるのである。

\section{2. 質換期に立つ LP ガス産業}

昭和 46 ・47年度にみられた工業用需要の急激な増加 は, 予想外に早いテンポで, 他然料からのL Pガスへ の転換が浸透しつつあることを示しているものといえ る (表 4-19 参照)。

\section{表 4-19 昭和48年度 52年度石油ガス需要見通し}

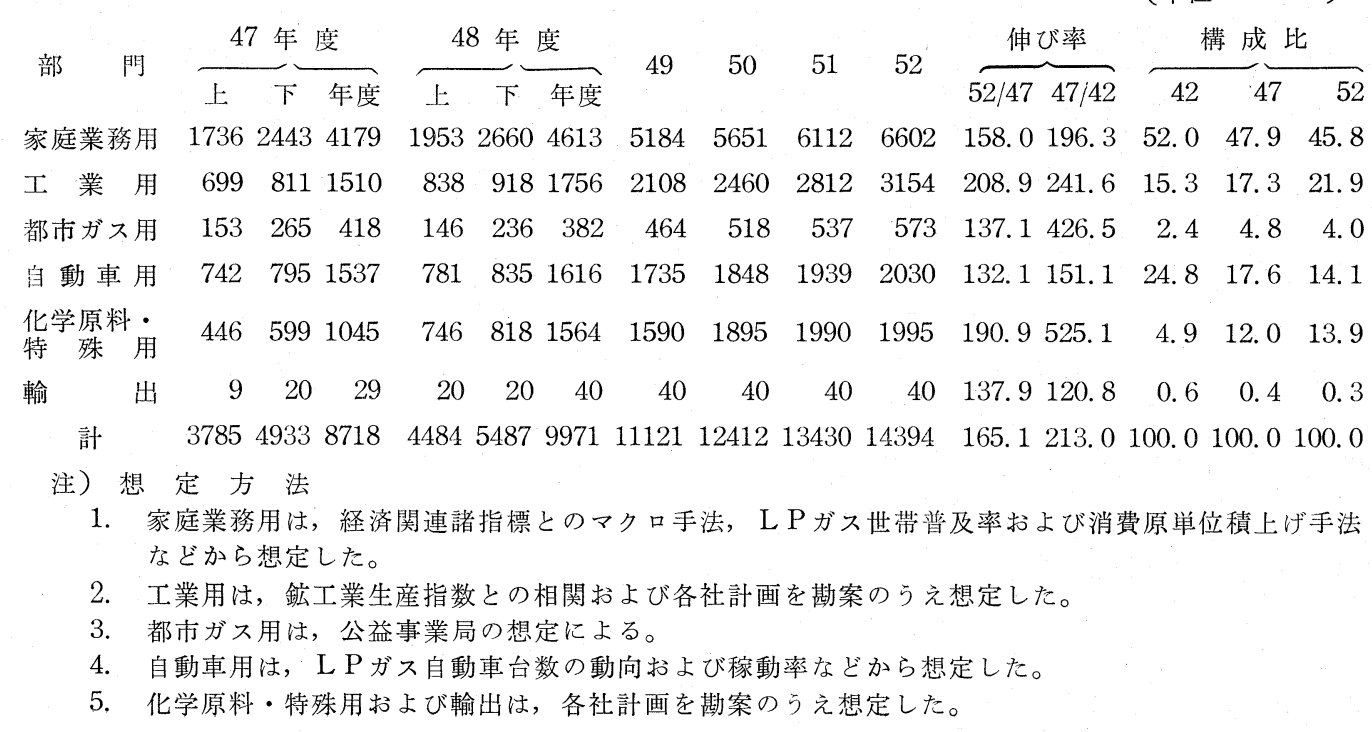


わが国の場合, 戦後の急速な経済発展と人口の著し い都市集中化とがからみあって，都市公害の度合いは ますます高まる傾向をみせているのがその実態であ り，大気污染，水質污濁などに代表される公害問題の 解決は，いまや国家的な課題として取り上げられるに 至っている。

このうちとくに注目を集めてきたのが，有毒な亜硫 酸ガスによる大気污染の公害問題である。

亜硫酸ガスは，重油などの燃料に含まれる硫黄分が 燃燒ガスとなって排出されるとき, 空気中の酸素と結 合することによって発生するが，L P ガスの場合液 化されたときの状態の硫黄分でさえ $0.005 \%$ と非常に 少なく, 燃焼する際には約 250 倍のガス体に膨張する ので，実際の使用にあたって硫黄分はほとんど 0 の状 態となる。

このため，L P ガスの燃焼ガスのなかには亜硫酸ガ スの発生はほとんど検出されないのが実情である。L Pガスが工業用燃料として各種業界の注目を集めてい るのは，このような無公害性によるものであることは
いらまでもない。

これらの点から, 長期 5 力年計画においても, L P ガスの工業用需要は大幅な増加が見込まれている。

L P ガス産業は, このような時期を迎えて，いわば 需要 ・供給の構造, 流通の構造の変化に対応す心゙き転 換期にたっているといえるであろう。

\section{3. 今後の供給体制}

L P ガスの供給は, 当初, 石油精製からの生産（製 油所生産）を主体としてスタートしたのであるが，昭 和36年に L P ガス泠凍タンカーによる輸入が始まって 以来, 急増する需要に対して供給を賄うために輸入の ウエイトは増大する一方となり, 現在ではすでに全供 給量に対して $50.9 \%$ （47年度 446 万 $8000 \mathrm{t}$ ）の比率を 占めるにいたっている。また今後も輸入のウエイトは 增大することが見込まれている。

これに対して国内生産は昭和 47 度で $49.1 \%$ (431万 $1000 \mathrm{t}$ ）と，その比率を低下させている。この国内生 産の内訳としては, 製油所生産 $90.0 \%$, 石油化学工場 生産 $9.7 \%$, 天然ガス鉱場生産 $0.3 \%$ となっている。

\section{表 4-20 昭和 48 52 年度石油 ガス需給計画}

(単位 : $1000 \mathrm{t}$ )

需給区分

給 $\begin{cases}\text { 生 輸 } & \text { 産 } \\ & \text { 計 }\end{cases}$

需 要

期 末 在 庫
47 年 度

上 期 下 期 年 度
$2008 \quad 2303 \quad 4311$ $\begin{array}{lll}1817 & 2651 & 4468\end{array}$ 3825 3785 774
$4954 \quad 8779$

$4933 \quad 8718$

$795 \quad 795$
48 年 度

上 期 下

$\begin{array}{lll}2257 & 2531 & 4788\end{array}$

$2311 \quad 2854 \quad 5165$

$4568 \quad 5385$

$4484 \quad 5487$

$879 \quad 777$
49

4933

6259

9953

9971

777
11192

11121

848
50

51

52

\section{$5187 \quad 5566 \quad 5905$}

$\begin{array}{lll}7293 & 7933 & 8564\end{array}$

$\begin{array}{lll}12480 & 13499 & 14469\end{array}$

$\begin{array}{lll}12412 & 13430 & 14394\end{array}$

$\begin{array}{lll}916 & 985 & 1060\end{array}$
昭和47年度の L P ガス生産輸入量は, 全体では 877 万9000 t であったが，とくに製油所に㧍けるL P ガス の得率には, 従来と大きな差異はみられず, 長期にわ たっても, 原油処理量の $3 \%$ 台で推移していくものと みられ，今後の供給体制としては輸入に依存せざるを えない状況である。

現在，L P ガスの輸入船は19隻に達しており, 年閒 輸入能力は約 470 万 $\mathrm{t}$ である。

現在の輸入先はサウジアラビア, クエート, イラン などの中東地域が $74.8 \%$ を占め，オーストラリア 19.6 $\%$ ，カナダ $5.6 \%$ がそれぞれ輸入されている。

このようにLPガス需要は, これからわが国経済成 長, 消費水準の向上とともに成長し, 貴重な無公害工 ネルギーとしてその重要性をますます高めていくこと になろら。

とはいえ, 輸入依存度が高まるといらことは, これ
からのエネルギー対策上からも慎重にその対策を進め ていかなければならない問題といえよう。

すなわち，47年 12 月のリヤド協定によって OPEC 諸国はパーティシペーションのとり決めに成功し，今 後はメジャ一に対する経営参加権を獲得したのである が，販売先をもたないため OPEC はその取得分をメ ジャーに買戻しさせることにならざるをえない。この 買戻しの価格に対しても， OPEC は強気の姿勢であ り, 日本のようなエネルギー消費国は, そのは社返り を転嫁されることにならうといわれている。

また, 世界のエネルギ一資源の点からみても, 従来 エネルギー供給国であったアメリカが大きく輸入国へ 転換して抢り，世界的なエネルギ一資源争奪戦が予想 されるほどである。

このような傾向から，世界のエネルギー事情は，従 来の多量消費型から貴重消費型へと向かわざるをえな 
いすう勢にある。

したがって，わが国の立場としては，いっそう簅し くなる世界の供給事情の中で，エネルギー資源をいか に確保するか，そしてまた，確保されたエネルギーを いかに有效に利用するかが十分検討されねばならなく なるであろう。

これらの情勢からすれば，原油をはじめL P ガスに いたるまで，わが国におけるエネルギーコストを上昇 させる外的要因は, 今後そらとう根強くなることが予 測される状況である。

\section{5 ガス化に関する研究}

ここでは, 固体燃料ならびに各種石油系炭化水素を 原料としてアセチレン，各種オレフィンガス，水素， 合成ガスおよび都市ガスの製造を目的とした反応と， 気体炭化水素の改質, 熱分解およびこれらの関連反応 について述べる。工業については他の項に詳述されて いるので, 本項では昨年度に公表された報文, 総説な どを中心に主に基礎的な研究を紹介する。

\section{1. 固体燃料のガス化}

石炭を原料としたガス化に関する総説としては，乾 留とガス化 ${ }^{1)}$ ，メタン ${ }^{23)}$ あるいは合成ガス ${ }^{4) 5)}$ の製造 に関していくつかあった。また地下ガス化に関する報 告はみられなかった。

ガス化剤を用いない石炭のガス化については, 熱分 解に関する動力学的研究 ${ }^{6)}$, 流動床についての基礎的 考察7)をはじめ, いくつかの熱分解に関する報文があ

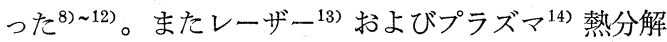
によるアセチレン製造についての研究，原子炉からの 熱によるガス化プロセス ${ }^{15)}$ についての報告などもみら れた。

一方, ガス化剤を用いた研究についても多くの報告 がみられ，合成ガスの製造を目的としたものでは，水 蒸気 ${ }^{16) ~ 18)}$, 水蒸気 - 酸素 $^{19)}$, 空気-水 ${ }^{20)}$ との反応に関 した報告があった。また一酸化炭素と炭酸ガスの混合 ガスとコークスとの反応速度 ${ }^{21)}$ およひ応メカニズ $\Delta^{22)}$, 炭酸ガスあるいは水蒸気と炭素との反応に関す る熱力学的考察23), パルス装置における石炭分解生成 物の水素化分解 ${ }^{24)}$ についての報告など基礎的な研究も みられた。
また加圧ガス化装置とタービンを組み合わせたプラ ント25)26)についての報告もみられた。

\section{2. 液体および気体炭化水素の分解, ガス化}

炭化水素の分解による不飽和炭化水素の生成に関す 研究注基礎的なものが多く，工業的なものは少な い。アセチレンの製造に関してはプラズマによる炭化 水素の分解 ${ }^{27) 28)}$ ，メタン ${ }^{29)}$ および液状炭化水素 ${ }^{30)}$ の電 気的熱分解, メタン ${ }^{31}$ およびプロパン ${ }^{32)}$ の酸素による 高温熱分解などについての報告があった。

エチレンなどのオレフィンガスの製造を目的とした 研究はかなり多いが, 以下気体, ガソリン, 重油など 原料別に研究報告を紹介する。気体原料よりオレフィ ンガスの製造を目的とした研究では，エタンの熱分

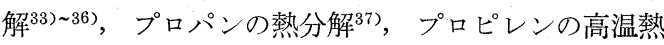
分解の反応速度論 ${ }^{38)}$, プロピレンープロパン混合物の 高速熱分解 ${ }^{39)}$ ， プラズマによるプロパンーブタン混合 物からのアセチレン，エチレンの製造40)，イソブタン 熱分解における反応速度および生成物分布 ${ }^{41}$ について の報告があった。比較的軽質の炭化水素からのオレフ インガス製造に関しては, ペンタン ${ }^{42)}, 1$-ペンテンの

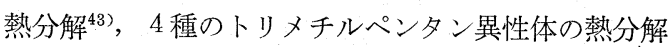
生成物 ${ }^{44)}$ などの純粋炭化水素についての研究をはじ め, 軽質ガソリンの触媒上での接触分解 ${ }^{45)}$, 水素気流 中における熱分解 ${ }^{46)}$, 軽油の放射線熱分解における動 力学 ${ }^{47)}$, その他の液体炭化水素の分解 ${ }^{48) ~ 51)}$ について の報告のほかに, ナフサ分解によるエチレンの製造に 関する総説 ${ }^{52)}$ もみられた。重質の炭化水素からのオレ フィン製造に関しては，高温スチームによる原油の熱 分解 ${ }^{53)}$, コークス上における重油の熱分解 ${ }^{54}$ について の報告のほかに, 総説としては重質油の分解技術など について比較検討したものが多くみられた

\section{3. 水素, 合成ガス, 都市ガスの製造を目的とす}

\section{るガス化}

昨年度も石油類の水蒸気改質による水素および合成 ガスの製造に関しては水素の需要と相まって多くの総

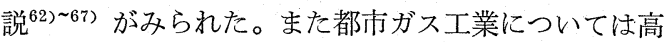
熱量ガスの製造に関する総説 $\left.{ }^{68)} 72\right)$ がほとんどであっ た。

水素，合成ガスの製造を目的としたガス化について は多くの研究が報告されている。メタンおよび天然 ガスを原料とした研究では加圧下における水蒸気改 質 ${ }^{7374)}$ ，触媒上での水蒸気 ${ }^{7576)}$ あるいは酸素77)78) との 反応についての報告があった。このほかに, 水蒸気改 質に関しては軽質炭化水素, ナフサを原料とした報 告 ${ }^{79)}$, 触媒の工業的試験の研究 ${ }^{80)}$ があり, 酸素を用い 
た部分燃焼に関しては動力学的な考察 ${ }^{81)}$ があった。ま た近年公害問題により注目されている重質油のガス化 については，前項で述べた熱分解による報告 ${ }^{53354) の ほ ~}$ かに, 高温, 高圧下に拈いて酸素とスチームによりガ ス化させる部分燃燒についての報告 ${ }^{82) 83) も あ っ た 。 ~}$

高熱量ガス製造法としての低温水蒸気改質に関して は, 天然ガスからナフサまでの炭化水素原料に対する 報告 ${ }^{84)}$ があった。

もう一つの都市ガス製造法である炭化水素の水素化 分解に関しては, 各種触媒上における基礎的な研究が 多くみられ，エタン ${ }^{85)}, n$-ペンタン ${ }^{86)}$, ヘキサン異性 体 ${ }^{87)}, n$-ヘプタン ${ }^{88)}, n$-ドデカン ${ }^{89)}, n$-ヘキサデカ ン90)などの純粋なパラフィン炭化水素に関する報告が あった。

\section{文 献*—*1972}

1) K. McG. Bowling, Coal Res. CSIRO, No. 45, 39 (1971)

2) G. E. Klingman et al., Hydrocarbon Process., 51, (4), 97

3) B. Sperski, Gaz, Woda Tech. Sanit., 46, (3), 92

4) F. C. Schora, Proc., Annu. Conv., Gas Process. Ass., Tech. Pap., 51, 114

5) P. Rudolph, Technology, 7, (No. 4) (Spec. Iss.), 116 (1970)

6) H. Wiser et al., J. Appl. Chem., 21, (3), 82 (1971)

7) C. Y. Wen, Air Pollut. Contr. Off. (U.S. ) Puble., AP-109, 111-6, 11

8) E. I. Kazakov et al., Vop. Energ. Ispol'z. Energ. Resur. Kirg., 260 (1970)

9) St. Donchev et al., God. Vissh. Khimikotekhnol. Inst., 14, (2), 207

10) H. Heek et al., Erdöl u. Kohle, 24, (9), 566 (1971)

11) R. R. Korropati et al., Erdoel Kohle, Erdgas, Petrochem. Brenst.-Chem., 25, (4), 191

12) V. G. Kashirskii et al., Nauch. Tr. Saratov. Politekh. Inst., No. 50, 39 (1971)

13) F. S. Karn et al., Fuel, 51, 113

14) R. Nicholson et al., Nature, 236,5347, 397

15) R. Nieder, Braunkohle, 24, (5), 159

16) S. V. Kaftanov et al., Khim. Tverd. Topl., (2), 105

17) V. J. Kavlick et al., AIChE Symp. Ser., 67, (116), 228 (1971)

18) E. J. Hoffman, Amer. Chem. Soc., Div. Petrol. Chem., Prepr., 16, (2), 20 (1971)

19) A. J. Forney, Air Pollut. Contr. Off. (U.S.) Puble., AP-109, 111, 5

20) G. P. Sechenov, Khim. Tverd. Topl., (3), 96
21) H. D. Beyer, Arch. Eisenhuettenw., 43, (8) 597

22) K. H. Ulrich, Tech. Mitt. Krupn. Forschungsber., 30, (1), 49

23) S. D. Fedoseev et al., Nauch. Tr. Saratov. Politekh. Inst., No. 50, 63 (1971)

24) I. A. Oshchepkov et al., Pererab. Tverd. Topl., (2), 198 (1970)

25) K. Bund et al., Brennstoff Warme Kraft, 23, (6), 258

26) P. Rudolph, Technology, 7, (No. 4) (Spec. Iss.), 112 (1970)

27）西村他，石油誌，15，(4)，299

28) 岡林他, 日化誌, No. 3, 609

29) J. Amouroux, et al., Ann. Chim., 6391 (1971)

30) N. S. Pechuro et al., Prom. Arm., (4), 15

31) G. G. Gumenyuk, Visn. L'vir. Politekh. Inst., No. 58, 65 (1971)

32) H. Bockhorn et al., Chem.-Ing.-Tech., 44, (14), 869

33) R. A. Kalinenko, et al., Dokl. Akad. Nauk SSSR, 204, (5), 1125

34) N. Bradley et al., J. Phys. Chem., 75, (10), 1492 (1971)

35) P. Muse, Oil Gas J., 69, (19), 67 (1971)

36) J. Muller et al., Compt. Rend. Hebd. Seances Acad. Sci. Ser. C, 272, (3), 271 (1971)

37) G. G. Hoyer et al., Chem. Eng. Comput., 1, 120

38) A. Sims et al., I. E.C. Process Design, Develop., 10, (2), 265 (1971)

39) K. K. Robinson et al., I.E.C. Fundamentals, 10, (2), 198 (1971)

40) Yu. V. Valibekov et al., Dokl. Akad. Nauk Tadzh. SSR, 15, (3), 32

41) G. Buekens et al., I.E.C. Process Design, Develop., 10, (3), 309 (1971)

42) И. Зыкова et al., Petrol. Chem. U.S.S.R., 11, (3), 381 (1971)

43) Р. Магарил et al., ibid., 11, (4), 483 (1971)

44) J. Q. Walker et al., Anal. Chem., 43, (12), 1548 (1971)

45) G. M. Panchenkov et al., Neftekhimiya, 12, (3), 349

46) А. М. Цыбулевский, Нефтехимия, 11, (5), 686 (1971)

47) G. M. Panchenkov, Zh. Fiz. Khim., 46, (6), 1438

48) A. Martens, Chromatographia, 5, (8), 467

49) E. Mosberger, Chem. Ingr. Tech., 43, (3), 131 (1971)

50) L. Blieck et al., Erdöl u. Kohle, 24, (7), 452 (1971)

51) T. Sato et al., Chem. Econ. Eng. Rev., 4, (7), 14

52) 服部, 化学工学, 36, (5), 513 
53）五味, 同誌, 36, (6), 610

54) P. L. Falyushin et al., Vestsi Akad. Navuk Belarus. SSR, Ser. Khim. Navuk, (2), 117

55) W. L. Pierce et al., Hydrocarbon Process., 51, (5), 92

56）森田，燃協誌，51，(539)，148

57) 徳久, 化学と工業, 26, (3), 137 (1973)

58）清水，燃協誌，52，(549), 12 (1973)

59) V. S. Aliev et al., Neftekhim. Neftepererab., 32 (1971)

60）飯島，燃協誌， 51，(541)，264

61）熟見，化学工業，23，(3)，39

62) D. K. Beavon, A.C.S. Div. Petrol. Chem. Inc., Preprints, 16, (2), C51 (1971)

63) A. Longacre, ibid., 16, (2), C32 (1971)

64) R. N. Beay, ibid., 16, (2), C67 (1971)

65) 播磿, 化学工場, 16, (1), 99

66) V. A. Zhukov, Teor. Prakt. Szhiganiya Gaza, 5, 149

67) C. J. Kuhre, Oil Gas J., 69, (36), 85 (1971)

68) H. Pichler, Mineraloele Verw. Prod., 1, 796 (2. Auflage 1969)

69) D. P. Thornton et al., Hydrocarbon Process., 51, (8), 81

70) S. Nojima, Chem. Econ. Eng. Rev., 4, (2), 9

71) J. A. Finneran, Oil Gas J., 70, (29), 83

72) D. Hebden et al., Inst. Gas. Eng., J., 12, (8), 229

73) A. R. Brun-Tsekhovoi, Neftepererab. Neftekhim., (6), 27
74) N. V. Karkhov et al., Tr. Nauch.-Issled. Proekt. Inst. Azotn. Prom. Prod. Org. Sin., No. 6, 67 (1971)

75) R. Rennhack et al., Erdöl u. Kohle, 25, 22

76) G. B. Shakhtakhtinskii, Issled. Obl. Neorg. Fiz. Khim., No. 2, 111 (1971)

77) D. Barrett, Ind. Eng. Chem., Process Des. Develop., 11, (3), 415

78) V. P. Mosidze, Sb. Tr. Molodykh Nauch. Sotrudnikov Aspir. Inst. Neorg. Khim. Elektrokhim. Akad. Nauck Gruz, SSR, 109 (1971)

79) 尹，石油誌， 15，(8)， 657

80) J. S. Cromeans et al., A.C.S. Div. Petrol. Chem. Inc., Preprints, 16, (2), C38 (1971)

81) P. Goehler, Freiberg. Forschungsh., 467, 25 (1969)

82) C. J. Kuhre, Hydrocabon Processing, 50, (12), 113 (1971)

83) W. G. Schlinger et al., A.C.S. Div. Petrol. Chem. Inc., Preprints, 16, (2), C45 (1971)

84) F. E. Hart, Hydrocarbon Processing, 52, (4), 94

85) L. Guczi et al., J. Catalysis, 24, (2), 187

86) E. Kikuchi et al., ibid., 22, (1), 226 (1971)

87) H. Matumoto et al., ibid., 22, (2), 182 (1971)

88) L. Carter et al., ibid., 20, (2), 223 (1971)

89) H. F. Schulz, Ind. Eng. Chem., Product Res. \& Develop., 11, (1), 46

90) T. Y. Yañ, J. Catalysis, 25, 204 